\title{
What causes neurodegenerative disease?
}

\author{
Richard Armstrong \\ Vision Sciences, Aston University, Birmingham, United Kingdom
}

\begin{abstract}
A hypothesis is proposed to explain the pathogenesis of neurodegenerative disease and the diversity of its phenotypes. The hypothesis is based on seven main propositions: 1) neurodegenerative disease is associated with multiple risk factors, 2) age is the most important of the risk factors, 3) aging differentially affects neuroanatomical pathways, 4) degeneration of these pathways results in the formation of pathogenic proteins, 5) pathogenic proteins spread along anatomical pathways, 6) the phenotypes of familial and sporadic forms of disease are similar and 7) neurodegenerative disease is characterised by heterogeneity, overlapping phenotypes, and multiple pathology. It is hypothesised that most cases of neurodegenerative disease are multifactorial in which interactions between external environmental and internal genetic risk factors act cumulatively over a lifetime to determine the 'allostatic load' of an individual. The allostatic load determines the rate of neural aging and results in the differential breakdown of neuro-anatomical pathways influenced by their relative use or disuse during life. The consequence is the formation of one or more pathogenic proteins, some of which may exhibit 'prion-like' behaviour and propagate through the brain from initial sites of formation along neuro-anatomical pathways to affect connected brain regions. Variations in the pathological proteins formed and their anatomical spread are ultimately responsible for the clinical and pathological diversity of disease phenotypes. Minimising the factors which contribute to the allostatic load over a lifetime and maximising cognitive and physical exercise may be necessary to reduce the incidence of neurodegenerative disease.
\end{abstract}

Key words: neurodegenerative disease, hypothesis, aging, allostatic load, cell to cell transfer.

\section{Introduction}

In 2019, approximately 50 million individuals worldwide had a neurodegenerative disease often resulting in dementia, a number expected to rise to 152 million by 2060 [2]. The overall prevalence of neurodegenerative disease leading to dementia, calculated by the European dementia meta-analysis (EURDEM) of all European studies, is $1.6 \%$ and $1 \%$ for males and females respectively in the 65-69 age class, rising to $11 \%$ and $12.6 \%$ in the $85-89$ age class [137]. Of the different types of dementia, $62 \%$ of cases are attributable to Alzheimer's disease (AD), 17\% to vascular dementia (VaD), $10 \%$ to a combination of $\mathrm{VaD}$ and $\mathrm{AD}$, while dementia with Lewy bodies (DLB) accounts for $4 \%$, frontotemporal dementia (FTD) for 2\%, Parkinson's disease dementia (PDD) for $2 \%$, and all other causes collectively for $3 \%$ of dementias $[77,79,84,125,137]$.

Given the present and future potential burden on health systems worldwide and the absence of effective therapies, credible hypotheses are needed which can explain the pathogenesis of neurodegenerative disease and which can provide a basis for new treatment strategies. In a previous review [14], it was suggested

\section{Communicating author}

Dr Phil. Richard A. Armstrong, Vision Sciences, Aston University, Aston Street, B4 7ET, Birmingham, United Kingdom,

phone: +441212044102, e-mail: R.A.Armstrong@aston.ac.uk 
that in $A D$, the most common neurodegenerative disease, genetic and environmental risk factors interact to increase the rate of normal aging ('the allostatic load') [57]. The allostatic load determines the degree of lifetime stress experienced by the body, the brain being the ultimate mediator of stress-related mortality through hormonal changes resulting in hypertension, glucose intolerance, cardiovascular disease, and immunological problems [57]. The consequent degeneration of neurons and blood vessels results in the formation of abnormally aggregated 'reactive' proteins. Hence, in AD, deposition of $\beta$-amyloid (A $\beta$ ) [95] and phosphorylated forms of the microtubule associated protein (MAP) tau [97] lead to the formation of the 'signature' lesions of $A D$, viz. senile plaques $(S P)$ and neurofibrillary tangles (NFT) respectively. Gene mutation may directly influence the outcome of this age-related neuronal degeneration in $A D$ by causing excessive amounts of $A \beta$ to be formed, which quickly overwhelms protection systems causing early-onset familial AD (EO-FAD). Where specific gene mutations are absent and a more complex combination of risk factors present, $A \beta$ and tau accumulate in the brain more slowly not overwhelming the cellular protection systems until much later in life causing late-onset sporadic AD (LO-SAD). Once formed, $A \beta$ and tau may exhibit 'prion-like' behaviour and spread through the brain via cell to cell transfer along neuroanatomical pathways to affect connected brain regions [98]. Subsequently, variations in the pathways of this spread may result in the clinical and pathological heterogeneity particularly characteristic of $A D$ [25].

The objective of this review is to extend this hypothesis to explain all forms of neurodegenerative disease [19]. The hypothesis is based on seven main propositions: 1) neurodegenerative disease is associated with multiple risk factors, 2) age is the most important of the risk factors, 3) aging differentially affects neuroanatomical pathways, 4) degeneration of these pathways results in the formation of pathogenic proteins, 5) pathogenic proteins spread along anatomical pathways, 6) the phenotypes of familial and sporadic forms of disease are similar and 7) neurodegenerative disease is characterised by heterogeneity, overlapping phenotypes, and multiple pathology.

\section{Proposition 1: Neurodegenerative disease is associated with multiple risk factors}

Early reviews identified many of the risk factors associated with dementia in general and $A D$ in particular [107,109-111,133]. Over 20 different risk fac- tors associated with AD were discussed by Henderson [109] and a common pathogenesis proposed as to how they might cause the pathological changes characteristic of the disease $[95,97]$. In a more recent review [20], a large number of risk factors were identified in $A D$, rare forms of EO-FAD being strongly linked to causal gene mutations, viz. mutations in amyloid precursor protein $(A P P)[59,96]$ and presenilin (PSEN1/2) genes [134,179]. By contrast, LO-SAD is a multifactorial disorder in which age-related changes, genetic risk factors, such as allelic variation in apolipoprotein E (Apo E) and many other genes [1], vascular disease, traumatic brain injury (TBI), and risk factors associated with diet, the immune system, mitochondrial function, metal exposure, and infection are all implicated (Table I). Moreover, over 60 environmental risk factors alone have been identified in $A D$ and classified into six categories, viz. air quality, heavy metals, other metals, trace elements, occupational exposure, and miscellaneous [124]. Although there are fewer data on risk factors in other disorders, in Parkinson's disease (PD), for example, higher body mass index [173], alcohol consumption [173], milk consumption [131], and low-income status [136], have all been linked to an increasing risk. It remains a major challenge to explain how so many apparently disparate risk factors could contribute to these disorders $[20,109]$.

\section{Proposition 2: Age is the most important risk factor}

Of the multiple risk factors associated with neurodegenerative disease, age has been consistently identified as the most important $[20,109]$. In addition, direct evidence that neurodegenerative disease may be an accelerated form of aging is provided most notably by $A D[60]$ and PD $[63,73]$. Most if not all AD neuropathological change (ADNC) [115,153] also occurs in normal aged brains [43]. Hence, in cognitively normal brain, there is an age-related reduction in volume and weight, enlargement of ventricles, and loss of synapses and dendrites in selected regions [116]. Accompanying these changes are the histological features of AD, viz., SP and NFT albeit at lower densities than controls $[3,36,45,145,183]$. A study of the changes in density of SP and NFT with age in 199 individuals suggests an abrupt increase in the numbers of both lesions in the early part of the seventh decade [150]. As a consequence, it is often difficult to distinguish early-stage $A D$ from normal 
Table I. List of risk factors associated with Alzheimer's disease (AD). Based on Henderson [109] and Armstrong [20]

\begin{tabular}{|c|c|}
\hline Grouping & Risk factor \\
\hline \multirow[t]{5}{*}{ Demographic } & Age \\
\hline & Education \\
\hline & Gender \\
\hline & Race \\
\hline & Social class \\
\hline \multirow[t]{15}{*}{ Genetics } & Amyloid precursor protein (APP) \\
\hline & Presenilin 1 and 2 (PSEN1/2) \\
\hline & Apolipoprotein E (APOE) \\
\hline & $\begin{array}{l}\text { ATP-binding cassette transporter } A 1 \text { (ABCA1) } \\
\text { Adaptor protein evolutionarily conserved } \\
\text { signalling intermediate in Toll pathway } \\
(E C S I T)\end{array}$ \\
\hline & Clusterin gene (CLU) \\
\hline & Estrogen receptor gene (ESR) \\
\hline & Fermitin family homolog 2 gene (FERMT2) \\
\hline & $\begin{array}{l}\text { Glyceraldehyde-3-phosphate dehydrogenase } \\
(G A P D H)\end{array}$ \\
\hline & Histocompatibility locus antigen (HLA class III) \\
\hline & mtDNA haplotype \\
\hline & Transferrin gene (Tf) \\
\hline & $\begin{array}{l}\text { Triggering receptor expressed on myeloid } \\
\text { cells } 2 \text { (TREM 2) }\end{array}$ \\
\hline & $\begin{array}{l}\text { Vascular protein sorting-10 domain (VpS10) } \\
\text { genes [108] }\end{array}$ \\
\hline & Vitamin D receptor gene (VDR) \\
\hline & Epigenetic factors \\
\hline \multirow[t]{5}{*}{ Lifestyle } & Alcohol \\
\hline & Lack of exercise, lack of cognitive activity \\
\hline & Malnutrition \\
\hline & Poor diet \\
\hline & Smoking \\
\hline
\end{tabular}

\begin{tabular}{|c|c|}
\hline Grouping & Risk factor \\
\hline \multirow[t]{10}{*}{ Medical } & Cancer \\
\hline & Cardiovascular disease \\
\hline & Congestive heart failure \\
\hline & Immune system dysfunction \\
\hline & Micro-infarcts \\
\hline & Obesity \\
\hline & Poor cholesterol homeostasis \\
\hline & Poorly controlled type-2 diabetes \\
\hline & Stroke \\
\hline & Traumatic brain injury (TBI) \\
\hline \multirow[t]{2}{*}{ Psychiatric } & Depression \\
\hline & Early stress \\
\hline \multirow[t]{8}{*}{ Environmental } & Air pollution \\
\hline & Calcium deficiency \\
\hline & Geographic location \\
\hline & Metals (especially aluminium, copper, zinc) \\
\hline & Military service \\
\hline & Organic solvents \\
\hline & Occupation \\
\hline & Vitamin deficiency \\
\hline \multirow[t]{4}{*}{ Infection } & $\begin{array}{l}\text { Bacteria, e.g., Chlamydophila pneumoniae, } \\
\text { Treponema }\end{array}$ \\
\hline & Dental infections \\
\hline & Fungi \\
\hline & Viruses \\
\hline
\end{tabular}

aging at post-mortem [145] and there may be a 'continuum' of pathological change from elderly non-demented brains, early-stage ('prodromal') AD, to more advanced AD [11].

Many studies have commented upon the frequency of ADNC in normal aging. First, certain morphological types of SP, i.e., those with a distinct central core ('classic plaques'), are encountered with greater frequency than expected in mentally able elderly [43], the density of classic SP in AD being similar to controls [42]. In addition, nearly all older individuals with no cognitive impairment exhibit ADNC, $75 \%$ with amyloid deposition, while $13 \%$ also have Lewy bodies (LB) [43]. In a study by Sonnen et al. [183], $47 \%$ of cognitively normal individuals had moderate

to frequent SP, $6 \%$ had NFT in layers V/VI of the cerebral cortex, and $15 \%$ had medullary LB. In addition, in 87 individuals clinically normal at death, 33 had ADNC, 17 had LB, and four had a pathology characteristic of progressive supranuclear palsy (PSP) [73]. A number of studies have also implicated vascular factors in the development of SP in the normal elderly. Hence, SP occur in frontal and temporal cortex in $15 / 20$ patients with critical stenosis, most often in the depths of the sulci [184] suggesting first, that alterations in cerebral perfusion may play a role in SP formation and second, that SP may not always be causally related to dementia. A further study of non-demented patients with critical coronary artery disease suggested that some patients had similar densities of SP to AD, numbers of SP being directly proportional to the duration of arterial disease [185].

$\beta$-amyloid is the major component of the SP in $A D[95]$ and there is quantitative overlap in deposition between $A D$ and normal aging $[7,19]$. $A \beta$ deposits 


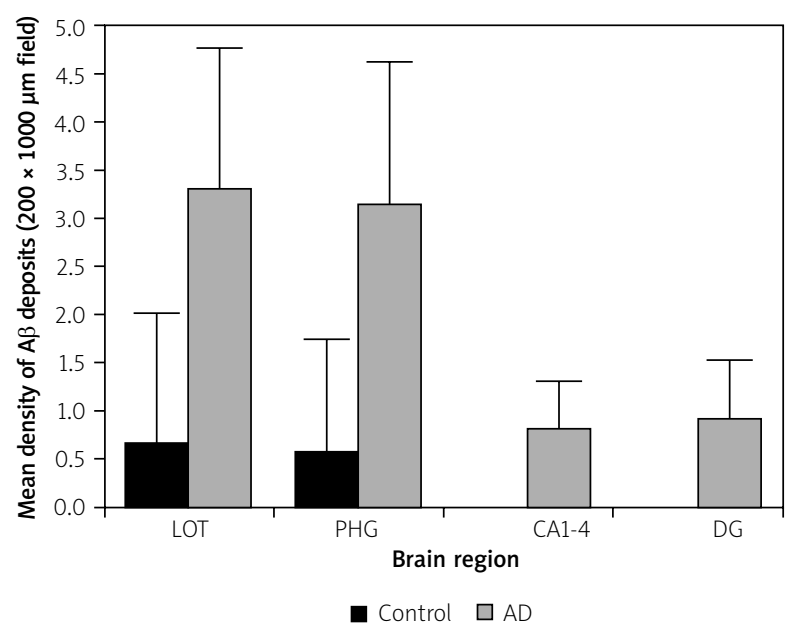

Fig. 1. Mean densities $(200 \times 1000 \mu \mathrm{m}$ sample field, with standard errors) of $\beta$-amyloid ( $A \beta$ deposits in regions of the medial temporal lobe (LOT - lateral-occipitotemporal gyrus, PHG parahippocampal gyrus, CA1-4 - cornus ammonis sectors of hippocampus, DG - dentate gyrus) in elderly non-demented control cases $(n=14)$ and Alzheimer's disease (AD) $(n=15)$. Data from Armstrong [7].

are frequently present in non-demented individuals older than 60 years but are rare before this age [146]. In addition, after 60 years, $A \beta$ deposits are present in a variety of disorders due to aging, especially in temporal cortex, thus blurring the distinction between $A D$ and related disorders [146]. In quantitative studies, the densities of $A \beta$ deposits in the medial temporal lobe (MTL) in elderly non-demented control cases, DLB, FAD and SAD show considerable overlap, some cases of $A D$ having low numbers of $A \beta$ deposits while some cognitively normal individuals have significantly greater numbers [7]. Figure 1 shows the density of $A \beta$ deposits in the MTL in normal elderly patients and in $A D$ and shows first, that in some regions, e.g., the lateral-occipitotemporal gyrus (LOT) and parahippocampal gyrus (PHG), there is considerable overlap in density and second, that there may be significant differences in the degree to which $A \beta$ pathology may affect the CA sectors of the hippocampus and the dentate gyrus, with little evidence of such deposition in control cases $[7,19]$. The spatial patterns of $A \beta$ deposits are also similar in control and $A D$ cases, i.e., deposits are aggregated into clusters that are regularly distributed parallel to the pia mater suggesting a common pathogenesis [7].
In a study of centenarians, $A \beta$ deposits were recorded in the PHG, whether the patient was demented or not, but the hippocampus was not affected and there was little relationship between lesion density and severity of mental deficit [69]. In addition, using Pittsburgh compound-B (PIR) positron emission tomography (PET), a specific marker for $A \beta, A \beta$ was observed in 10-30\% of healthy elderly [165].

The frequency and abundance of tau pathology in normal aging has been more controversial. Many individuals cognitively normal at death have minimal tau-immunoreactive NFT [126] and with less astrocytosis or microglial reaction [62]. By contrast, Bouras et al. [48] found that all non-demented cases had NFT at least in layer II of the entorhinal cortex and sector CA1 of the hippocampus. Moreover, in non-demented individuals, NFT were more numerous in the MTL and in cortical association areas if memory deficits were present suggesting NFT could be the pathological substrate for memory loss in non-demented as well as demented cases [100]. Tau-immunoreactive NFT also appear early in the locus coeruleus in normal aging, mild cognitive impairment $(\mathrm{MCl})$, and $A D$, apparently forming a continuum [99]. Within the MTL, however, the perforant path appears particularly sensitive to tau pathology in $A D$ and these changes may be distinct from those seen in controls even in the oldest individuals [86].

The distinction between aging and neurodegenerative disease is further blurred by the discovery of 'primary age-related tauopathy' (PART), a tau-immunoreactive pathology present associated with aging and independent of amyloid pathology $[64,72]$. PART is characterised by: 1) a diffuse cerebral atrophy most severe in the temporal lobe, 2) NFT in the MTL, hippocampus, and amygdala, 3) extracellular 'ghost' tangles, and 4) sparse diffuse $A \beta$ deposits but with very few SP $[64,72]$. Hence, PART may describe a pathological condition intermediate between that of normal aging and the tauopathies.

Phosphorylation and truncation of $\alpha$-synuclein are characteristic of the 'synucleinopathies' PD, DLB, and multiple system atrophy (MSA) and are also normal events in adult human brain [156]. Phosphorylation and nitration of $\alpha$-synuclein have been observed in dopamine neurons in the substantia nigra as a result of normal aging in monkey brain [149]. Age-related elevation of modified protein also paralleled an increase in the number of neurons immunoreactive for unmodified $\alpha$-synuclein suggesting a mechanis- 
tic link between aging, $\alpha$-synuclein abundance, and enhanced vulnerability to neurodegeneration. In addition, in 110 cognitively normal individuals, 36\% exhibited transactive response (TAR) DNA-binding protein (TDP-43) pathology, a hallmark of a common subtype of fronto-temporal lobar degeneration (FTLD) [56]. Finally, many cognitively normal individuals exhibit the signs of two or more different pathologies $[29,73,119]$. Hence, in the normal elderly, the presence of ADNC alone may double the chance of developing a cognitive impairment while multiple pathologies further increase the risk [207].

\section{Proposition 3: Aging differentially affects anatomical pathways}

The efficiency of brain function depends on both its long and short-range anatomical connections, there being fewer long-range connections as greater resources are required to maintain them [101]. Normal adolescence is characterised by selective strengthening of the long-range connections while in disorders such as schizophrenia, there is a widespread synaptic disconnection, in which there is a disproportionate reduction in long-range connections affecting subcortical, inter-hemispherical, and pathways associated with the 'will to persevere' ('salience network') [101]. There are also marked structural changes in the brain with age including cortical thinning, degradation of myelin, and reduced connectivity [106,200]. This reduced connectivity often results in a functional reorganisation later in life to compensate for the structural losses attributable to aging [106]. Several pathways appear to be particularly vulnerable. First, aging affects the 'structural covariance networks' which are involved in the language-related semantic, the executive control, and the default-mode networks [152]. Second, changes in hippocampus volume occur accompanied by thinning of the entorhinal cortex, which can affect memory function before reductions are evident in the default-mode network [199]. Third, both increases and reductions in functional connectivity affect the resting state motor network [182]. Fourth, there are selective age-related alterations in synaptic connectivity associated with rapid sensory learning [154]. Fifth, visual changes in aging, such as a decline in visual acuity, spatial contrast sensitivity, temporal frequency sensitivity, spatial-temporal interactions, binocular processing, and response to motion are likely to be attributable, not to specific changes in the eye, but to aging affecting the retino-cortical pathway and central visual pathways [186].

In neurodegenerative disease, there is enhanced disruption of connectivity principally affecting the long-range connections to hub nodes with consequent loss of network efficiency [135]. Hence, there is a functional continuum between healthy aging, $\mathrm{MCl}$, and early $A D$ [191] with in $\mathrm{MCl}$, a decrease in antero-posterior functional connectivity [38] and in $A D$, a further decline in the efficiency of connections associated with more localised modular organisation of the cortex and related regions resulting in less effective local communication [191]. There are significant variations, however, in the anatomical pathways affected in different disorders (Table II) [17]. Hence, the disruption of afferent and efferent connections between the hippocampal formation and the rest of the brain is especially characteris-

Table II. The main neuro-anatomical pathways affected in various neurodegenerative disorders

\begin{tabular}{|lcc|}
\hline Disorder & Cortical/Subcortical & Anatomical pathways affected \\
\hline AD & Primarily cortical & Afferent and efferent connections between HC and rest of brain \\
\hline CBD & Cortical/subcortical & $\begin{array}{c}\text { Pathways involving GP and SN significantly affected. } \\
\text { Pathology spreading to affect cerebral cortex }\end{array}$ \\
\hline DLB & Cortical/subcortical & Neocortical, limbic, and brainstem in different subtypes \\
\hline FTLD & Primarily cortical & Largely frontal/temporal HC less affected than in AD \\
\hline FTLD-17 & Cortical/subcortical & Pathways involving GP and SN significantly affected \\
\hline FTLD-MND & Cortical/subcortical & Motor pathways including motor cortex and spinal cord \\
\hline MSA & Primarily subcortical & SN, striatum, ION, cerebellum \\
\hline PD & Cortical/subcortical & Subcortical in PD. Spread to cortex in PDD \\
\hline
\end{tabular}

$A D$ - Alzheimer's disease, DLB - dementia with Lewy bodies, FTLD - fronto-temporal lobar degeneration, FTLD-17 - fronto-temporal lobar degeneration with parkinsonism linked to chromosome 17, CBD - corticobasal degeneration. FTLD-MND - fronto-temporal lobar degeneration with motor neuron disease, MSA - multiple system atrophy, PD - Parkinson's disease, HC - hippocampus, GP - globus pallidus, SN - substantia nigra, MC - motor cortex, ION - inferior olivary nucleus, PDD - Parkinson's disease with dementia 
tic of $A D$, essentially isolating the hippocampus [67]. There also may be anatomical differences in the pathways affected in $A D$ and DLB, the primary visual cortex (area V1) being more affected $[138,151]$ and the hippocampus less affected in DLB [39]. In FTLD, the pathological changes predominantly affect frontal and temporal lobes [188] but with selective anatomical degeneration within various members of this group $[22,32,46,91,167]$. By contrast, disorders such as MSA, PD, and PSP exhibit a predominantly subcortical pathology at least in the initial stages $[16,28,71,118,132,141,180,202]$.

The selective disruption of anatomical pathways observed in different disorders could be the result of the aging process differentially affecting anatomical pathways. One factor which could determine such selectivity is the relative degree of use or lack of use during a lifetime. Hence, in individuals that suffer early blindness, there is a significant reduction in white matter volume in the optic tracts and radiation and significant loss of grey matter in visual cortex [162]. The reduction in grey matter volume progresses with age and duration of blindness, suggesting a response to lack of functional activity in the relevant pathways. In aged rats, voluntary running can restore presynaptic density in the dentate gyrus and sector CA3 of the hippocampus to levels greater than in younger animals suggesting that activity may reverse degradation of the hippocampal network due to aging [181]. Moreover, moderate intensities of physical activity may protect against volumetric brain loss most commonly affecting pre-frontal cortex and the hippocampus [75]. In a further study, regular physical activity resulted in pathways being less affected by typical age-related decline in cognitive function [106]. In addition, individuals who exercised regularly reduced the risk of $A D$, the beneficial effect mediated by the effect of brain-derived neurotrophic factor (BDNF) on neuroplasticity and stress resistance [158]. In PD, there is evidence that heavy leisure-time physical activity lowers the risk suggesting continued activity in motor pathways reduces specifically their rate of aging [173]. In addition, treadmill exercise in a murine model of PD improved motor performance and reduced $\alpha$-synuclein expression while promoting the expression of tyrosine hydroxylase, dopamine transfer, and plasma dopamine levels [128]. Hence, differential aging resulting from variations in the level of activity could be a fac- tor influencing the anatomical selectivity observed in neurodegenerative disease [17].

\section{Proposition 4: Neurodegeneration results in the formation of pathogenic proteins}

Abnormally aggregated or misfolded proteins have played an important role in diagnosis, classification, and studies of pathogenesis [80]. A key question is: are these proteins the causal factor or a later consequence of age-related neurodegeneration [27]? Several observations suggest the latter. First, each of the different subtypes of $A \beta$ deposit in $A D$ viz., the diffuse, primitive, and classic deposits $[8,68]$ are associated with specific anatomical features. Hence, diffuse $A \beta$ deposits have a close spatial association with clusters of larger neuronal cell bodies [9], primitive deposits with synapto-axonal degeneration not involving the cell body [90], and classic deposits with cerebral blood vessels [10]. These results suggest that degeneration of a particular anatomical structure results in the release of $A \beta$ and subsequently the formation of a deposit with a specific morphology [8]. Extracellular protein deposits also occur in prion disease in the form of prion protein ( $\mathrm{PrPs}^{\mathrm{sc}}$ ) deposits which vary in morphology. Hence, 'synaptic-type' PrPsc deposits occur in the 'classical' form of sporadic Creutzfeldt-Jakob disease (SCJD) [178] while 'florid-type' plaques are characteristic mainly of the variant form of CJD (VCJD) [117]. In addition, in the cerebellum of VCJD cases, synaptic-type deposits occur almost exclusively within the molecular layer while florid plaques are confined to the granular layer suggesting, as in AD, that morphological differences are related to degeneration of specific cell types and anatomical structures [31].

Second, the morphology and molecular constituents of cellular inclusions are dependent on cell type and location. Hence, in AD, cortical and subcortical NFT comprise morphologically similar but antigenically different paired helical filaments (PHF) [192]. By contrast, cortical and brain stem LB are morphologically different but antigenically similar [51], brainstem LB having an electron-dense core with radially oriented filaments differing significantly from cortical LB. In the tauopathies, inclusions are consistently present in both neurons and glia especially in PSP, corticobasal degeneration (CBD), and Pick's disease (PiD) [127] and different pools of tau isoforms within degenerating cells appear to be characteristic of the 
various disorders [54]. These data suggest differences in molecular composition of inclusions depend on the degeneration of the cell types expressing these constituents [53] and therefore, that their formation could be determined by the anatomical pathways which age most rapidly.

Third, $\alpha$-synuclein immunoreactive glial cytoplasmic inclusions $(\mathrm{GCl})$ are composed of $10-15 \mathrm{~nm}$ coated filaments and are characteristic of MSA [132]. $\alpha$-synuclein is enriched at presynaptic terminals and reversibly binds to lipid vesicles, and hence, may be an integrator of presynaptic signalling associated with membrane function [40,61]. Hence, in DLB, PDD and MSA synaptic disconnection may result in the release of $\alpha$-synuclein which is taken up by glial cells accumulating as $\mathrm{GCl}$.

Fourth, in some cases of traumatic brain injury (TBI), amyloid precursor protein (APP) is observed in neuronal perikarya and in the dystrophic neurites (DN) surrounding $A \beta$ deposits. Processing of APP within the synaptic terminal fold of axons into $A \beta$ suggests the production of APP may be a component of the brain's response to neuronal injury [89]. In addition, specific neurons in the MTL secrete large quantities of APP and more APP-immunoreactive neurons occur in these areas in TBI cases [148]. Hence, increased expression of APP after head trauma could be an acute-phase response to neuronal injury [171], the overexpression of APP leading to increased deposition of $A \beta$. Several acute-phase proteins are localised within $A \beta$ deposits in $A D$ including amyloid-P, complement factors, and $\alpha$-antichymotrypsin [121]. Furthermore, it was proposed that in AD, APP helps to maintain cell function, an observation supported by the fact that APP shares structural features with the precursor for epidermal growth factor [168].

Fifth, in lesion experiments, damage to the nucleus basalis in the rat decreased cortical choline acetyltransferase (CAT), elevated somatostatin and neuropeptide $Y$ [5], and caused neuronal loss and the formation of SP in the cortex. Lesions of the nucleus basalis also elevated APP synthesis in the cerebral cortex suggesting a specific response to loss of functional innervation [198]. Furthermore, 4-7 days after damage to the nucleus basalis, APP was present in axonal varicosities, cell bodies, and DN as a consequence of the inhibition of axonal transport [189]. In addition, chemically induced lesions of the nucleus basalis using N-methyl D-aspartate (NMDA) elevat- ed APP synthesis in cortical polysomes [198] and, in areas of brain damaged by kainite [123], APP 695 occurred in DN close to the lesion. In addition, intrathecal or intra-parenchymal injections of excitotoxin induced APP in hippocampal neurons subsequent to neuronal damage [122].

Sixth, tau formation may also be part of the neurons response to injury [203]. Hence, denervation of dopamine pathways and septal lesions affect both the cholinergic system and GABA neurons projecting to the dentate gyrus, and result in a loss of dendritic MAP2 and the appearance of tau-immunoreactive dentate gyrus granule cells [194]. Denervation may also cause trans-synaptic changes in the dentate gyrus and these changes could be a precursor to NFT. Axonal injury may also result in the cytoplasmic accumulation of $\alpha$-synuclein, an important constituent of LB [157]. Moreover, primates given 1-methyl4-phenyl-1,2,3,6-tetrahydropyridine (MPTP) developed inclusion-type bodies which may result from the redistribution of $\alpha$-synuclein from its normal synaptic location to the cell body [130].

\section{Proposition 5: Pathological proteins spread along anatomical pathways}

Several observations suggest an association between neurodegenerative disease and the breakdown of specific neuro-anatomical pathways. First, loss of synaptophysin reactivity has been reported in the cortex in AD suggesting synapse loss, especially in temporal lobe [177], while a decrease in the synaptic marker SP6 has been found in all regions of AD brain [197]. Second, NFT in AD are located in cell bodies that give rise to the cortico-cortical pathways, SP forming at their ends and on collateral branches $[67,163]$. Disease could therefore spread along these pathways in either an orthograde and/or retrograde direction [67]. In addition, ADNC appears to have an anatomical basis as regions severely affected are interconnected by the cortico-cortical pathways [112]. The most complete description of this 'disconnection hypothesis' of AD is the seminal review by De Lacoste and White [67] in which the disease is characterised by disruption of all afferent/ efferent connections between the hippocampus, cerebral cortex, and the rest of the brain. The cortico-cortical pathways appear selectively vulnerable in $A D$, the pathology spreading in stages via these connections $[67,163]$, SP developing on the distal 
axonal projections of NFT-bearing neurons [67]. In addition, Hoesen and Solodkin [113] demonstrated that NFT were associated with cortical pathways in $A D$, as they selectively damaged strips of cortex and hippocampus, with columns of resulting NFT exhibiting a regular periodicity $(80-120 \mu \mathrm{m})$ representing $4-5$ cell diameters and with a spacing of $300 \mu \mathrm{m}$. With greater duration of disease, NFT gradually 'filled up' the columns giving rise to clusters of NFT of increasing size, a result also reported by Armstrong [6].

Populations of neurons that are lost in a particular disease are often functionally related and share a common metabolic abnormality and therefore, neuronal connections between different regions could specify the pattern of cell losses in each disease [175]. Subsequently, it was shown that pathogenic proteins such as tau and $\alpha$-synuclein can be secreted from cells, enter other cells, and seed small intracellular aggregates within these cells $[98,187]$. This raises the possibility, originally with reference to PD, that pathogenic agents may transfer along unmyelinated axons to basal areas of brain, the brain stem and then to the cerebral cortex [105]. If pathogenic proteins spread from cell to cell, then the resulting inclusions may exhibit a spatial distribution which reflects this process. A number of studies have suggested non-random distributions of inclusions in the cerebral cortex of various disorders including not only the tauopathies and synucleinopathies but also TDP-43 and 'fused in sarcoma' (FUS) proteinopathies, the inclusions often exhibiting a distinct clustering pattern, i.e., a regular distribution of clusters parallel to the pia mater, consistent with their spread via cortico-cortical pathways $[21,26]$ (Table III). Hence, once formed as a consequence of age-related breakdown of anatomical pathways several resulting proteins may have the ability to propagate among regions thus causing phases of secondary degeneration which could involve more local circuits and glial cells.

\section{Proposition 6: The phenotypes of familial and sporadic cases are similar}

Studies have demonstrated similarities in the pathology of familial and sporadic forms of various diseases. Hence, variations in the distribution and abundance of SP and NFT in 23 brain regions were compared in sporadic and familial AD using principal components analysis (PCA) [25]. Cases of AD formed a large cluster, pathological change varying continuously across the cluster and with no clear distinction between SAD and FAD (Fig. 2). In addition, there are

Table III. Frequency of the different types of spatial pattern ( $\mathrm{R}$ - random, U/RG - uniform or regular, RGC regularly distributed clusters, 50-1600 $\mu \mathrm{m}$ in diameter, LC - large clusters, $\geq 1600 \mu \mathrm{m}$ in diameter without regular spacing) exhibited by pathological inclusions in the cortex of various neurodegenerative disorders

\begin{tabular}{|c|c|c|c|c|c|c|c|c|}
\hline \multirow[t]{2}{*}{ Disorder } & \multirow{2}{*}{$\begin{array}{l}\text { Molecular } \\
\text { pathology }\end{array}$} & \multicolumn{7}{|c|}{ Type of spatial pattern } \\
\hline & & $\mathrm{NCl}$ & $N$ & $\mathrm{R}$ & U/RG & RGC & $\mathrm{LC}$ & $\%$ RGC \\
\hline$A D$ & 3R/4R tau & NFT & 30 & 1 & 0 & 22 & 7 & 73 \\
\hline AGD & $4 \mathrm{R}$ tau & NFT & 61 & 15 & 2 & 30 & 9 & 49 \\
\hline CBD & 4R tau & $\mathrm{NCl}$ & 76 & 2 & 2 & 48 & 24 & 63 \\
\hline CTE & 3R/4R tau & NFT & 42 & 11 & 11 & 15 & 5 & 36 \\
\hline DLB & $\alpha$-synuclein & $\mathrm{LB}$ & 70 & 2 & 1 & 43 & 24 & 61 \\
\hline FTDP-17 & 3R/4R tau & NFT & 13 & 3 & 2 & 5 & 3 & 38 \\
\hline FTLD-TDP & TDP-43 & $\mathrm{NCl}$ & 49 & 18 & 1 & 27 & 3 & 55 \\
\hline GPDC & 3R/4R tau & NFT & 16 & 2 & 2 & 9 & 3 & 56 \\
\hline MSA & $\alpha$-synuclein & $\mathrm{NCl}$ & 9 & 5 & 0 & 3 & 1 & 33 \\
\hline NIFID & FUS & $\mathrm{NCl}$ & 53 & 7 & 3 & 39 & 4 & 74 \\
\hline PiD & $3 R$ tau & PB & 48 & 1 & 0 & 27 & 20 & 53 \\
\hline PDD & $\alpha$-synuclein & LB & 41 & 9 & 2 & 28 & 2 & 68 \\
\hline PSP & 4R tau & NFT & 23 & 11 & 0 & 10 & 2 & 43 \\
\hline
\end{tabular}

$A D$-Alzheimer's disease, AGD - argyrophilic grain disease, CTE - chromic traumatic encephalopathy, DLB - dementia with Lewy bodies, FTLD - fronto-temporal lobar degeneration, FTLD-17 - fronto-temporal lobar degeneration with parkinsonism linked to chromosome 17, GPDC - Guam parkinsonism dementia complex, PiD - Pick's disease, CBD - corticobasal degeneration, FTLD-TDP - fronto-temporal lobar degeneration with TDP-43 proteinopathy, MSA - multiple system atrophy, NIFID - neuronal intermediate filament inclusion disease, PD - Parkinson's disease, PSP - progressive supranuclear palsy, FUS - 'fused in sarcoma', $N F T$ - neurofibrillary tangles, NCl-neuronal cytoplasmic inclusions, $P B$-Pick bodies, $N$-total number of cortical regions analysed for each disorder 
no essential differences in the spatial patterns of $A \beta$ deposits in FAD and SAD, both being distributed similarly in regularly spaced clusters [12]. There are no differences either in the spatial pattern in $A D$ cases expressing or not expressing the Apo E e4 allele, a major risk factor for $A D[176,190]$. Furthermore, the laminar distribution of $A \beta$ deposits, an indicator of the pattern of degeneration across the cortical layers, is similar in both FAD and SAD, maximum density of the diffuse and primitive $A \beta$ deposits occurring in upper cortical layers while the distribution of the classic $A \beta$ deposits is more variable occurring either in the lower layers, or in both upper and lower layers [16]. The cortical layer where $A \beta$ deposits reached maximum density and the maximum density is also similar in FAD and SAD. In addition, there are no significant differences in distribution in cases expressing one or more Apo E e4 alleles compared with cases not expressing this allele. These results suggest that gene expression had relatively little effect on the pattern of cortical degeneration in FAD and SAD.

Similar results have also been reported in FTLD with TDP-43-immunoreactive pathology (FTLD-TDP). A significant number of familial cases of FTLD-TDP are caused by defects in the chromosome 9 open reading frame 72 (C90RF72) gene [66,140,169] and the progranulin $(G R N)$ gene $[41,65,155,166]$. Rarer cases are caused by mutations of the TAR DNA-binding protein (TARDBP) [94,204] TANK-binding kinase 1 (TBK1) [93], and valosin-containing protein (VCP) genes [81,201]. A quantitative study of 94 cases of FTLD-TDP using PCA, suggested that as in AD, the familial cases as a whole did not have a pathological phenotype that was distinct from the sporadic cases [32]. In addition, the frequencies of the different types of laminar distribution in FTLD-TDP associated with GRN mutations [15] was similar to those previously reported in sporadic FTLD-TDP [33] suggesting that the GRN mutations were not associated with a specific pattern of laminar degeneration in FTLD-TDP.

\section{Proposition 7: Neurodegenerative disease is characterised by heterogeneity, overlap, and multiple pathology}

Any hypothesis to explain neurodegenerative disease has to account for the diversity and complexity of its clinical and pathological phenotypes [13]. Three aspects of neurodegenerative disease contribute to this diversity: 1) the degree of heterogeneity within individual disorders $[25,32], 2)$ the degree of over- lap or 'interface' between closely-related disorders $[11,29]$, and 3) 'multiple pathology', i.e., the co-existence of two or more different pathologies in the same case [119,205].

Considerable variations in the severity and distribution of the pathology have been observed within many neurodegenerative diseases, most notably in AD $[25,83,195]$ and FTLD [32,56]. Three hypotheses may account for this heterogeneity [170]. First, that within each disease there are distinct subtypes ('subtype hypothesis'). For example, AD consists of both sporadic and familial forms, the latter associated with mutations of at least three genes, viz., APP [59,96], and presenilin genes PSEN1 [179] and PSEN2 [134]. More complex forms of AD have also been described, e.g., $A D$ in combination with $P D$ [47], or AD with DLB [70], AD with significant degeneration of white matter [52], VaD [109], or with capillary amyloid angiopathy (CAA) [196]. Studies suggest that FTLD-TDP is also diverse [32] with division into four possible subtypes (currently designated $A$, $B, C$, and D) based on the distribution and density of 'signature' pathological inclusions in the cortex $[56,120,142-144,174]$. Second, heterogeneity may reflect the stage of the disease present at death ('phase hypothesis') and therefore, may be related

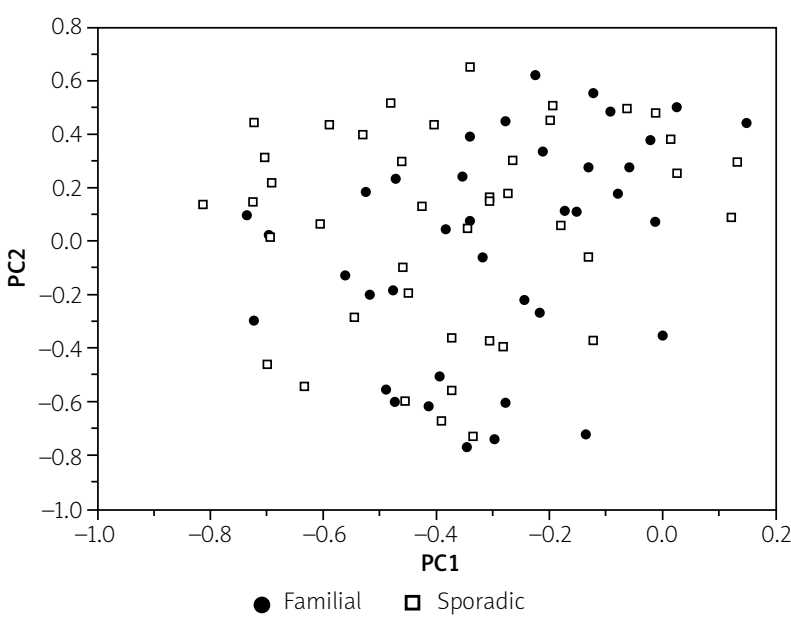

Fig. 2. Principal components analysis (PCA) of Alzheimer's disease (AD) cases $(N=80)$ based on the distribution and severity of senile plaques (SP) and neurofibrillary tangles (NFT) in 23 cortical and subcortical brain regions. A plot in relation to the first two principal components (PCA1/2) illustrating the relative similarity among cases. Data from Armstrong et al. [25]. 
to disease duration [50]. Third, there may be topographical variations in the site or sites of initial neurodegeneration followed by differences in the subsequent propagation of the pathology through the brain ('compensation hypothesis') $[67,163]$.

Many studies have reported overlaps between closely related disorders $[78,82,102]$. Many such overlaps involve $A D$, reflecting both its prevalence and the fact that ADNC has been recorded in the majority of non-AD disorders. Hence, $A D$ and $V a D$ commonly coexist, $18 \%$ of a dementia autopsy series showing evidence of both [109]. In addition, overlaps have also been reported among the various tauopathies, synucleinopathies, within FTLD, and between AD and CJD [29].

Third, more complex examples of 'multiple pathology' have been reported which cannot be explained as simply a region of 'overlap' between two relatively distinct disorders. For example, the number of pathologies encountered in cases comprising a selection of neuropathological studies is shown in Table IV. Of a total of 417 cases, 204 (49\%) had evidence of at least one additional co-pathology. In addition, in studies of the parkinsonian syndromes, $38 \%$ of cases of PD have ADNC, $9 \%$ PSP, $25 \%$ argyrophilic grains (ARG), and 24\% CAA while in DLB, $89 \%$ have ADNC pathology, 1\% PSP, 21\% ARG, and 25\% CAA [73]. Overlap among parkinsonian syndromes is very evident between PSP and CBD and between PDD and DLB, questioning whether these disorders are actually distinct [44]. In addition, in a recent comparative study of 1032 cases representing ten different disorders, 361 cases, approximately $35 \%$ of the sample, were excluded largely as a result of mul- tiple pathology [35]. Some neurodegenerative diseases may even be indistinguishable, cases essentially forming a 'continuum' in which there is gradual clinical and pathological change from one case to another [13]. The frequent use by authors of such terms as 'complex syndrome' $[58,87,193]$, 'spectrum of disorders' [88], or 'continuum' $[13,58,87,193]$ testifies to the extent to which there may be no distinct boundaries between neurodegenerative disorders.

Multiple pathology may be the result of either the random co-occurrence of different disorders or that one pathology may induce or encourage the presence of another. Hence, the coexistence of features of $A D$ and $P D$ or $A D$ and $V a D$ in the same case may be frequent because both disorders are common and show a rapid increase in incidence with age [47]. In Table IV, the frequency of cases revealing 0, 1, 2, or 3 additional pathologies totalled over the various studies does not deviate significantly from a Poisson distribution $\left(\chi^{2}=0.16, p=0.92\right)$ suggesting that the frequency of multiple pathology diminishes rapidly with the increasing number of co-pathologies consistent with chance associations. Nevertheless, if two disorders are truly independent and their co-existence is random, their joint occurrence should approximate to the product of their respective prevalence rates. On this basis, the combination $A D / V a D$ is more frequent than predicted suggesting either that the effects of mild $A D$ and $V a D$ are additive thus increasing the likelihood of detecting the combination or that the ischaemia resulting from $\mathrm{VaD}$ accelerates the formation of ADNC [109]. In addition, $A D$ and $P D$ may be found together more commonly

Table IV. Frequency of 'multiple pathology' in a selection of neuropathological studies of neurodegenerative disease

\begin{tabular}{|c|c|c|c|c|c|c|}
\hline \multirow[t]{2}{*}{ Primary diagnosis } & \multirow[t]{2}{*}{ Number of cases } & \multicolumn{5}{|c|}{ Number of associated pathologies } \\
\hline & & 0 & 1 & 2 & $3+$ & Reference \\
\hline$A D$ & 101 & 43 & 52 & 2 & 0 & {$[25]$} \\
\hline AGD & 25 & 4 & 4 & 15 & 2 & UP \\
\hline CTE & 11 & 1 & 1 & 5 & 4 & [34] \\
\hline FTD & 56 & 38 & 17 & 0 & 1 & UP \\
\hline FTLD & 128 & 78 & 44 & 6 & 0 & {$[32]$} \\
\hline PDD & 32 & 12 & 19 & 1 & 0 & [129] \\
\hline 'Various dementias' & 45 & 24 & 19 & 2 & 0 & {$[205]$} \\
\hline 'Various tauopathies' & 19 & 9 & 8 & 1 & 1 & [18] \\
\hline Total & 417 & 209 & 164 & 32 & 8 & \\
\hline
\end{tabular}

AD-Alzheimer's disease, AGD - argyrophilic grain disease, CTE - chronic traumatic encephalopathy, DLB - dementia with Lewy bodies, FTLD - fronto-temporal lobar degeneration, PDD - Parkinson's disease dementia, UP - R.A. Armstrong unpublished data 
than expected based on prevalence [47]. In a pathological study of PD patients, a high proportion had the characteristic symptoms of AD with SP, NFT, and granulovacuolar change in the hippocampus [103]. The apparent frequency of patients combining the features of $A D$ and PD suggests a common aetiology [47]. As a consequence, there has been a search for unifying concepts to explain this co-occurrence, e.g. failure of neurotrophic hormone causing retrograde degeneration [4] or that $A D$ and $P D$ are both disorders of the 'isodendritic core' [172].

The presence of one type of pathology could encourage or induce the formation of another. An important aspect of the 'amyloid cascade hypothesis' $(A C H)$ of $A D$ is that the formation of $A \beta$ directly causes NFT [104]. Several attempts have been made, however, to explain how $A \beta$ may lead to NFT, but none have become universally accepted $[55,92,160,161]$. Hence, SP and NFT occur alone separately in different disorders, e.g., NFT in tangle-only dementia [206] and $A \beta$ in hereditary cerebral haemorrhage with amyloidosis of the Dutch type (HCHA-D) [114]. Studies also suggest that SP and NFT exhibit distinct but independently distributed topographic patterns in the cerebral cortex in AD [23,114]. Braak and Braak [49] showed that tau pathology occurred first in entorhinal cortex, often in the absence of SP, whereas the subsequent spread and distribution of $A \beta$ was more variable. Studies of the spatial patterns of SP and NFT also show them to be clustered, the clusters being regularly distributed relative to the pia mater [23]. Clusters of SP and NFT, however, are not in a phase, which would not support a direct pathogenic link between them. Perez et al. [164], however, showed that $A \beta_{25-35}$ could result in tau aggregation and that a decrease in $A \beta$ aggregation was induced by tau peptides. Consequently, aggregation of tau may be correlated with disassembly of $A \beta$ which could explain the lack of spatial correlation [24]. In addition, SP and NFT may be temporally separated in the brain [147]; in entorhinal cortex [74] and in sector CA1 of the hippocampus [85], for example, NFT may precede the appearance of SP against the prediction of the $\mathrm{ACH}$. In sector $\mathrm{CA} 1$, it is possible that $A \beta$ is present in neurons before NFT are formed but not easily detectable by conventional methods [85].

A likely explanation of multiple pathology is that it is the consequence of the diversity of pathological proteins that are formed as a result of age-related neurodegeneration and their pattern of spread in the nervous system, a version of the 'compensation hypothesis' first proposed to explain heterogeneity in $A D[25,170]$. Allelic variations among individuals determine which pathologic proteins are formed and variation in spread determines which pathways are affected thus creating a possible 'continuum' of clinical and pathological forms of disease [13]. Ultimately, the clinical features of an individual patient may depend on the anatomical pathways affected, the rate of spread of one or more proteins, and the summation of their pathological effects over the nervous system as a whole.

\section{Discussion}

\section{The hypothesis}

First, the primary cause of neurodegenerative disease is accelerated aging and is determined by the allostatic load (Fig. 3). This process results in differential aging of anatomical pathways, especially the more vulnerable long-range connections, related, in part, to their degree of use or disuse during life.

Second, the consequence of this neural aging is gradual synaptic disconnection, neuronal degeneration, and the upregulation, release, and deposition of various reactive and breakdown products such as A $\beta$, tau, $\alpha$-synuclein, TDP-43, and FUS $[121,168,198]$. The most overt manifestation of this process is in those individuals in which specific mutations or allelic polymorphisms influence directly the outcome of age-related degeneration by determining the solubility and/or toxicity of the molecular products [30]. Cells have mechanisms to protect against the accumulation of misfolded and aggregated proteins including the ubiquitin system [76] and the phagosome-lysosome system [159]. In individuals with specific gene mutations, accelerated formation of an insoluble, misfolded protein may rapidly overwhelm these protection systems. Early-onset familial disease is the consequence of this process. By contrast, in individuals without a specific genetic mutation, but where more complex allelic variation and/or environmental risk factors are present, the outcome of age-related loss of synapses is mainly soluble and smaller quantities of several insoluble proteins which are degraded by the cellular protection systems and do not significantly accumulate to form pathogenic lesions. With advancing age, how- 


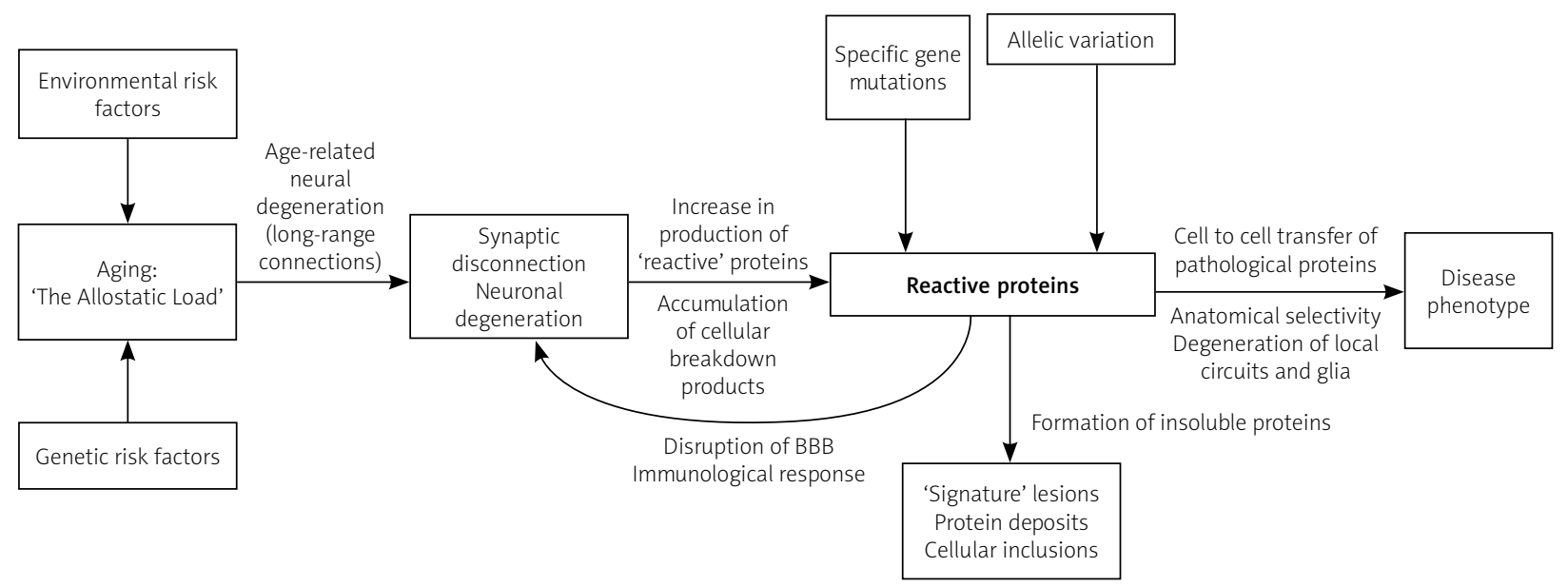

Fig. 3. A hypothesis to explain neurodegenerative disease. BBB - blood brain barrier.

ever, the protective systems become less effective resulting in slowly accumulating quantities of insoluble proteins. As a result, the cellular protection systems do not become overwhelmed until much later in life, the result being late-onset sporadic forms of disease often phenotypically similar to their familial counterparts $[12,15,16]$. In other individuals, the accumulating allostatic load may not be severe enough to result in significant synaptic disconnection during their lifetime, and death may intervene from other causes before such individuals succumb to an age-related neurodegenerative disease.

Third, once abnormal proteins are formed they spread 'prion-like' through the brain by cell to cell transfer along interconnected neuroanatomical pathways $[98,187]$ and increasingly affect more local circuits and associated glial cells. As a consequence, there may be disruption of the blood brain barrier, release of plasma proteins, and further neural degeneration adjacent to blood vessels, as can be observed in $A D$ [10]. There is considerable evidence to support the hypothesis that PrPsc, tau and $\alpha$-synuclein propagate through the brain via anatomical pathways $[98,187]$, and also indirect evidence that A $\beta$, TDP-43, and 'fused in sarcoma' (FUS) proteins may behave similarly (Table IV) [22]. As they spread, these proteins may contribute to further degeneration by acting as foci for the accumulation and growth of protein deposits and encouraging more local degeneration. Variation in the molecular phenotype results from: 1) differential vulnerability of specific neural pathways, 2) individual genotypic variation which affects the outcome of cellular degeneration and therefore, the number, type, and frequency of pathological proteins [30], and 3) variations in the pathways of spread of various proteins along neuroanatomical pathways. These processes result in the complex overlap of different pathologies with cases of neurodegenerative disease likely to form a continuum rather than comprising a series of distinct disorders [13].

\section{Implications}

The hypothesis suggests that neurodegenerative disease constitutes a single complex syndrome dependant on the rate of aging and determined by the allostatic load and its differential effects on the nervous system. These processes result in a continuum of pathological change not only from normal aging, through $\mathrm{MCl}$, to $\mathrm{AD}$ but also among the different forms of neurodegenerative disease. A major future challenge will be to explain how all possible variants of neurodegenerative disease are formed and therefore, to account completely for the diversity of resulting disease phenotypes. Subsequently, it will be necessary to establish a system for describing this diversity, i.e., should a classificatory system be used or does neurodegenerative disease represent such a continuum of clinical and pathological change, that it is not amenable to any type of classification $[13,17]$ ? New systems may need to be devised to provide a framework for the description of all variants of disease. A recent review [17] proposed four key neuropathological features (the 'primary determinants') that could be used to pro- 
vide such a framework, viz., the anatomical pathways affected by the disease ('anatomy'), the cell populations affected ('cells'), the molecular pathology of 'signature' pathological lesions ('molecules'), and the morphological types of neurodegeneration ('morphology'). These primary determinants could be used in combination with quantitative methods based on multivariate geometry to describe all cases of neurodegenerative disease [17].

If the cumulating allostatic load is the most important factor causing neurodegenerative disease, should the presence, distribution, and molecular composition of pathogenic lesions continue to play such a dominant role in description and diagnosis? If abnormal proteins are the products of brain degeneration and not their primary cause, then they may occur at various stages and possibly even late in the disease. Hence, there may be cases of disease that are difficult to identify because they may have insufficient numbers of deposits or inclusions or exhibit early developmental stages of these pathologies.

A major implication of the hypothesis is that it is unlikely that neurodegenerative disease will be amenable to treatment by simple pharmacological intervention [108]. Therefore, should significant effort continue to be devoted to immunotherapy and other treatments designed to remove specific pathogenic proteins from the brain? Removing $A \beta$ in $A D$, for example, could be beneficial in limiting its spread and therefore, the degree of secondary degeneration, potentially slowing the progress of the disease. However, $A \beta$ and other proteins might also be beneficial to the nervous system by promoting neurogenesis [139] and having a range of other protective functions. Hence, excessive removal of $A \beta$ could reduce chelation within the brain and result in enhanced oxidative stress [37]. By contrast, the present hypothesis suggests that attention should also be directed to reducing those factors which contribute to the life-time allostatic load [57] and to encourage activity through life, which contributes to exercising both cognitive and motor pathways. Therefore, there is an urgent need to develop strategies to slow down cognitive and motor decline resulting from aging. This process will require the identification of modifiable lifestyle and health-related variables to identify optimal combinations of such factors which could slow down the accumulating allostatic load [108].

Finally, there are individuals that reach considerable age without developing a neurodegenerative disease and which represent a 'survival elite' [109]. The hypothesis predicts that such individuals should be associated with fewer known risk factors and carry a low allostatic load. Such individuals may even possess 'protective factors' which may actively reduce the risk of neurodegenerative disease and more studies of such individuals are urgently needed.

\section{Conclusions}

This review proposes a hypothesis to explain the different forms of neurodegenerative disease based on seven main propositions: 1) neurodegenerative disease is associated with multiple risk factors, 2) age is the most important of the risk factors, 3) aging differentially affects neuroanatomical pathways, 4) degeneration of these pathways results in the formation of pathogenic proteins, 5) pathogenic proteins spread along anatomical pathways, 6) the phenotypes of familial and sporadic forms of disease are similar and 7) neurodegenerative disease is characterised by heterogeneity, overlapping phenotypes, and multiple pathology. The hypothesis suggests that there is unlikely to be a simple solution to the treatment of neurodegenerative disease. Instead, reducing the extent of the allostatic load over a lifetime and encouraging activity to exercise both motor and cognitive brain pathways especially in later life may be necessary to reduce the incidence of neurodegenerative disease.

\section{Disclosure}

The author reports no conflict of interest.

\section{References}

1. Allen M, Cox C, Belbin O, Ma L, Bisceglio GD, Wilcox SL, Howell CC, Hunter TA, Culley O, Walker LP, Carrasquillo MM, Dickson DW, Petersen RC, Graff-Radford NR, Younkin SG, Ertekin-Taner N. Association and heterogeneity at the GAPDH locus in Alzheimer's disease. Neurobiol Aging 2012; 33: 203.e25-33.

2. Alzheimer's Disease International, 2019. www.alz.co.uk/research/ statistics.

3. Anderton BH. Ageing of the brain. Mech Ageing Dev 2002; 123: 811-817.

4. Appel SH. A unifying hypothesis for the cause of amylotrophic lateral sclerosis, parkinsonism and Alzheimer disease. Ann Neurol 1981; 10: 499-505.

5. Arendash GW, Millard WJ, Dunn AJ, Meyer EM. Long term neuropathological and neurochemical effects of nucleus basalis lesions in the rat. Science 1987; 238: 952-956.

6. Armstrong RA. Is the clustering of neurofibrillary tangles in Alzheimer's patients related to the cells of origin of specific cortico-cortical projections? Neurosci Lett 1993; 160: 57-60. 
7. Armstrong RA. Beta-amyloid deposition in the medial tempora lobe in elderly non-demented brains and in Alzheimer's disease. Dementia 1995; 6: 121-125.

8. Armstrong RA. $\beta$-amyloid plaques: stages in life history or independent origin? Dement Geriatr Cogn Disord 1998; 9: 227-238.

9. Armstrong RA. Diffuse $\beta$-amyloid ( $A \beta$ ) deposits and neurons: in situ secretion or diffusion of A $\beta$ ? Alzheimer's Rep 2001; 3: 289-294.

10. Armstrong RA. Classic $\beta$-amyloid deposits cluster around large diameter blood vessels rather than capillaries in sporadic Alz heimer's disease. Curr Neurovasc Res 2006; 3: 289-294.

11. Armstrong RA. The interface between Alzheimer's disease, normal aging and related disorders. Current Aging Sci 2008, 1: $122-132$.

12. Armstrong RA. Spatial patterns of $\beta$-amyloid $(A \beta)$ deposits in familial and sporadic Alzheimer's disease. Folia Neuropatho 2011; 49: 153-161

13. Armstrong RA. On the classification of neurodegenerative dis orders: discrete entities, overlap or continuum? Folia Neuropathol 2012; 50: 201-218.

14. Armstrong RA. What causes Alzheimer's disease? Folia Neuropathol 2013; 51: 169-188.

15. Armstrong RA. Cortical degeneration in frontotemporal lobar degeneration with TDP-43 proteinopathy caused by progranulin gene mutation. Int J Neurosci 2014; 124: 894-903.

16. Armstrong RA. Laminar distribution of $\beta$-amyloid $(A \beta)$ peptide deposits in the frontal lobe in familial and sporadic Alzheimer's disease. Folia Neuropathol 2015; 53: 15-23.

17. Armstrong RA. Can neurodegenerative disease be defined by four 'primary determinants': anatomy, cells, molecules, and morphology. Folia Neuropathol 2016; 54: 89-104.

18. Armstrong RA. The quantitative analysis of neurodegenerative disease: classification, noda, constellations, and multivariate geometry. Folia Neuropathol 2018; 56: 1-13.

19. Armstrong RA. A possible explanation for neurodegenerative disease. EMJ Neurol 2019; 7: 80-89.

20. Armstrong RA. Risk factors for Alzheimer's disease. Folia Neuropathol 2019; 57: 87-105.

21. Armstrong RA, Cairns NJ. Different molecular pathologies result in similar spatial patterns of cellular inclusions in neurodegenerative disease. J Neural Transm 2012; 119: 1551-1560.

22. Armstrong RA, Cairns NJ. Comparative quantitative study of 'sig nature' pathological lesions in the hippocampus and adjacent gyri of twelve neurodegenerative disorders. J Neural Transm 2015; 122: 1355-1367.

23. Armstrong, RA, Myers D, Smith CUM, Cairns N, Luthert PJ. The spatial pattern of senile plaques, neurofibrillary tangles and A4 deposits in Alzheimer's disease. Neurosci Res Comms 1992; 10: 27-33.

24. Armstrong RA, Myers D, Smith CUM. The spatial patterns of plaques and tangles in Alzheimer's disease do not support the 'Cascade hypothesis'. Dementia 1993; 4: 16-20.

25. Armstrong RA, Nochlin D, Bird TD. Neuropathological heterogeneity in Alzheimer's disease: A study of 80 cases using principal components analysis. Neuropathology 2000; 1: 31-37.

26. Armstrong RA, Lantos PL, Cairns NJ. What does the study of spatial patterns of pathological lesions tell us about the pathogenesis of neurodegenerative disorders. Neuropathol 2001; 21: 1-12.
27. Armstrong RA, Cairns NJ, Lantos PL. Are pathological lesions in neurodegenerative disorders the cause or the effect of the degeneration? Neuropathology 2002; 22: 114-127.

28. Armstrong RA, Cairns NJ, Lantos PL. A quantitative study of the pathological changes in ten patients with multiple system atrophy (MSA). J Neural Transm 2004; 111: 485-495.

29. Armstrong RA, Lantos PL, Cairns NJ. Overlap between neurodegenerative disorders. Neuropathology 2005; 25: 111-124.

30. Armstrong RA, Lantos PL, Cairns NJ. What determines the molecular composition of abnormal protein aggregates in neurodegenerative disease? Neuropathology 2008; 28: 351-365.

31. Armstrong RA, Ironside JW, Lantos PL, Cairns NJ. A quantitative study of the pathological changes in the cerebellum in 15 cases of variant Creutzfeldt-Jakob disease (vCJD). Neuropathol Appl Neurobiol 2009; 35: 36-45.

32. Armstrong RA, Ellis W, Hamilton RL, Mackenzie IRA, Hedreen J, Gearing M, Montine T, Vonsattel J-P, Head E, Lieberman AP, Cairns NJ. Neuropathological heterogeneity in frontotemporal lobar degeneration with TDP-43 proteinopathy: a quantitative study of 94 cases using principal components analysis. J Neural Transm 2010; 117: 227-239.

33. Armstrong RA, Hamilton RL, Mackenzie IRA, Hedreen J, Cairns NJ. Laminar distribution of the pathological changes in sporadic frontotemporal degeneration with transactive response (TAR) DNA-binding protein of 43kDa (TDP-43) proteinopathy: A quantitative study using polynomial curve fitting. Neuropathol Appl Neurobiol 2013; 39: 335-347.

34. Armstrong RA, McKee AC, Stein TD, Alvarez VE, Cairns NJ. A quantitative study of tau pathology in 11 cases of chronic traumatic encephalopathy. Neuropathol Appl Neurobiol 2016; 43: 154-166.

35. Arnold SE, Toledo JB, Appleby DH, Xie SX, Wang LS, Baek Y, Wolk DA, Lee EB, Miller BL, Lee VM, Trojanowski JQ. Comparative survey of the topographical distribution of signature molecular lesions in major neurodegenerative disease. J Comp Neurol 2013; 521: 4339-4353.

36. Arriagada PV, Marzloff K, Hyman BT. Distribution of Alzheimer-type pathologic changes in non-demented elderly individuals matches the pattern in Alzheimer's disease. Neurology 1992; 42: 1681-1688.

37. Atwood CS, Obrenovich ME, Liu T, Chan H, Perry G, Smith MA, Martins RN. Amyloid-beta: a chameleon walking in two worlds: a review of the trophic and toxic properties of amyloid- $\beta$. Brain Res Rev 2004; 43: 1-16.

38. Bajo R, Maestu F, Nevado A, Sancho M, Gutierrez R, Campo P, Castellanos NP, Gil P, Moratti S, Pereda E, del-Pozo F. Functional connectivity in mild cognitive impairment during memory task: Implications for the disconnection hypothesis. J Alzheimers Dis 2010; 22: 183-193.

39. Barber R, McKeith IG, Ballard C, Gholkar A, O'Brien JT. A comparison of medial and lateral temporal lobe atrophy in dementia with Lewy bodies and Alzheimer's disease: Magnetic resonance imaging volumetric study. Dement Geriatr Cogn 2001; 12: 198-205.

40. Bayer TA, Jakala P, Hartmann T, Havas L, McLean C, Culverov JG, Li QX, Masters CL, Falkai P, Beyreuther K. Alpha-synuclein accumulates in Lewy bodies in Parkinson's disease and dementia 
with Lewy bodies but not in Alzheimer's disease beta amyloid plaque cores. Neurosci Lett 1999; 266: 213-216.

41. Behrens MI, Mukherjee O, Tu PH, Liscic RM, Grinberg LT, Carter D, Paulsmeyer K, Taylor-Reinwald L, Gitcho M, Norton JB, Chakraverty S, Goate AM, Morris JC, Cairns NJ. Neuropathologic heterogeneity in HDDD1: a familial frontotemporal lobar degeneration with ubiquitin-positive inclusions and progranulin mutation. Alz Dis Rel Disord 2007; 21: 1-7.

42. Bell M, Ball M. Neuritic plaques and vessels of visual cortex in ageing and Alzheimer's dementia. Neurobiol Aging 1990; 11 359-370.

43. Bennett DA, Wilson RS, Boyle PA, Buchman AS, Schneider JA. Relation of neuropathology to cognition in persons without cog. nitive impairment. Ann Neurol 2012; 728: 599-609.

44. Berg D, Postuma RB, Bloem B, Chan P, Dubois B, Gasser T, Goetz CG, Halliday GM, Hardy J, Lang AE, Litvan I, Marek K, Obeso J, Oertel W, Olanow CW, Poewe W, Stern M, Deuschi G. Time to redefine PD? Introductory statement of the MDS Task Force on the definition of Parkinson's disease. Movement Disord 2014; 29: 454-462.

45. Bergeron C, Ranalli PJ, Miceli PN. Amyloid angiopathy in Alzheimer's disease. Can J Neurol Sci 1987; 14: 564-569.

46. Bergmann M, Kuchelmeister K, Schmid KW, Kretzschmar HA, Schroder R. Different variants of FTD: a neuropathological and immunohistochemical study. Acta Neuropathol 1996; 92: 170-179.

47. Boller F. Alzheimer's disease and Parkinson's disease: clinical and pathological associations. In: Reisberg B (ed.). Alzheimer's disease: The standard reference. MacMillan, London 1983; 295-302.

48. Bouras C, Hof PR, Morrison JH. Neurofibrillary tangle densities in the hippocamal formation in a non-demented population define subgroups of patients with differential early pathologic changes. Neurosci Lett 1993; 153: 131-135.

49. Braak H, Braak E. Neuropathological staging of Alzheimer-related changes. Acta Neuropathol 1991; 82: 239-259.

50. Braak H, Braak E, Bohl J. Retrosplenial region involvement in Alzheimer's disease. Neurodegeneration 1992; 1: 53-57.

51. Brion JP, Couk AM. Cortical and brain stem type Lewy bodies are immunoreactive for the cyclin dependent kinase-5. Am J Pathol 1995; 147: 1465-1476.

52. Brun A, Englund E. A white matter disorder in dementia of the Alzheimer type: a pathoanatomical study. Ann Neurol 1986; 19: 253-262.

53. Buee L, Delacourte A. Comparative biochemistry of tau in progressive supranuclear palsy, corticobasal degeneration, fronto-temporal dementia with parkinosonism linked to chromosome 17, and Pick's disease. Brain Pathol 1999; 4: 681-693.

54. Buee-Scherrer V, Hof PR, Buee L, Levengle B, Vermersch P, Perl D, Olanow CW, Delacourte A. Hyperphosphorylated tau proteins differentiate corticobasal degeneration and Pick's disease. Acta Neuropathol 1996; 91: 351-359.

55. Busciglio J, Lorenzo A, Yeh J, Yankner BA. $\beta$-amyloid fibrils induce tau phosphorylation and loss of microtubule binding. Neuron 1995; 14: 879-888.

56. Cairns NJ, Bigio EH, Mackenzie IRA, Neumann M, Lee VMY, Hatanpaa KJ, White CL, Schneider JA, Grinberg LT, Halliday G, Duyckaerts C, Lowe JS, Holm IE, Tolnay M, Okamoto K, Yokoo H,
Murayama S, Woulfe J, Munoz DG, Dickson DW, Ince PG, Trojanowski JQ, Mann DMA. Neuropathologic diagnostic and nosological criteria for frontotemporal lobar degeneration: consensus of the Consortium for Frontotemporal Lobar Degeneration. Acta Neuropathol 2007; 114: 5-22.

57. Carroll BJ. Ageing, stress and the brain. Novartis Found Symp 2002; 242: 26-36.

58. Caselli RJ. Asymmetric cortical degeneration syndrome. Curr Opin Neurol 1996; 9: 276-280.

59. Chartier-Harlin MC, Crawford F, Houlden H, Warren A, Hughes D, Fidani, L, Goate A, Rossor M, Rocques P, Hardy J, Mullan M. Early onset Alzheimer's disease caused by mutations at codon 717 of the $\beta$-amyloid precursor protein gene. Nature 1991; 353: 844-846.

60. Cholerton B, Larson EB, Baker LD, Craft S, Crane PK, Millard SP, Sonnen JA, Montine TJ. Neuropathologic correlates of cognition in a population-based sample. J Alzheimers Dis 2013; 36: 699709.

61. Clayton DF, George JM. Synucleins in synaptic plasticity and neurodegenerative disorders. J Neurosci Res 1999; 58: 120-129.

62. Coria F, Moreno A, Rubio I, Garcia MA, Morato E, Major F. The cellular pathology associated with Alzheimer $\beta$-amyloid deposits in non-demented aged individuals. Neuropath Appl Neurobiol 1993; 19: 261-268.

63. Collier TJ, Kanaan NM, Kordower JH. Ageing as a primary risk factor for Parkinson's disease: evidence from studies of non-human primates. Nat Rev Neurosci 2011; 12: 359-366.

64. Crary JF, Trojanowski JQ, Schneider JA, Abisambra JF, Abner EL, Alafuzoff I, Arnold SE, Attems J, Beach TG, Bigio EH, Cairns NJ, Dickson DW, Gearing M, Grinberg LT, Hof PR, Hyman BT, Jellinger K, Jicha GA, Kovacs GG, Knopman PS, Kofler J, Kukull WA, McKenzie IR, Masliah E, McKee A, Montine TJ, Murray ME, Neltner JH, Santa Maria I, Seeley WW, Serramo-Pozo A, Shelanski ML, Stein T, Takao M, Thal DR, Toledo JB, Troncoso J, Vonsattel JP, White CL, Wisniewski T, Woltzer RL, Yamada M, Nelson PT. Primary age-related tauopathy (PART): a common pathology associated with human aging. Acta Neuropathol 2014; 128: 755-766.

65. Cruts M, Gijselink I, van der ZJ, Engelborgs S, Wils H, Pirici D, Radamakers R, Vandenberghe R, Dermaut B, Martin JJ, van Duijn C, Peeters K, Sciot R, Santens P, De Pooter T, Mattheijssens M, van Den Broeck M, Cuijt I, Vennekens K, De Deyn PP, KumarSingh S, Van Broeckhoven C. Null mutations in progranulin cause ubiquitin-positive frontotemporal dementia linked to chromosome 17q21. Nature 2006; 442: 920-924.

66. De Jesus-Hernandez M, Mackenzie IR, Boeve BF, Boxer AL, Baker M, Rutherford NJ, Micholson AM, Finch NA, Flynn H, Adamson J, Kouri N, Wojtas A, Sengdy P, Josephs KA, Coppola G, Geschwind DH, Wszolek ZK, Feldman H, Knopman DS, Petersen RG, Muller BL, Dickson DW, Boylan LB, Graff-Radford NR, Rademakers R. Expanded GGGGCC Hexanucleotide repeat in non-coding region of C9ORF72 causes chromosome 9p-linked FTD and ALS. Neuron 2011; 72: 245-256.

67. De Lacoste M, White CL III. The role of cortical connectivity in Alzheimer's disease pathogenesis: a review and model system. Neurobiol Aging 1993; 14: 1-16.

68. Delaere P, Duyckaerts C, He Y, Piette F, Hauw J. Subtypes and differential laminar distribution of $\beta / A 4$ deposits in Alzheimer's dis- 
ease: Relationship with the intellectual status of 26 cases. Acta Neuropathol 1991; 81: 328-335.

69. Delaere P, He Y, Fayet G, Duyckaerts C, Hauw J. $\beta$ A4 deposits are constant in the brains of the oldest old: An immunocytochemical study of 20 French Centenarians. Neurobiol Aging 1993; 14: 191-194.

70. Dickson DW, Ruan D, Crystal H, Mark MH, Davies P, Kress Y, Yen SH. Hippocampal degeneration differentiates diffuse Lewy body disease (DLBD) from Alzheimer's disease: Light and electron microscope immunocytochemistry of CA2-3 neurites specific to DLBD. Neurology 1991; 41: 1402-1409.

71. Dickson DW, Lin WL, Liu WK, Yen SH. Multiple system atrophy: a sporadic synucleinopathy. Brain Pathol 1999; 9: 721-732.

72. Dickson DW. Neuropathology of non-Alzheimer degenerative disorders. Int J Clin Exp Patho 2009; 3: 1-23.

73. Dugger BN, Adler CH, Shell HA, Caviness J, Jacobsen S, DriverDinckey E, Beach TG. Concomitant pathologies among a spectrum of parkinsonian disorders. Parkinsonism Relat D 2014; 20: 525-529.

74. Duyckaerts C. Looking for the link between plaques and tangles. Neurobiol Aging 2004; 25: 735-739.

75. Erickson KI, Hohmann T. The effects of age and training on cognitive health. Z Sportpsychol 2013; 20: 25-32.

76. Etlinger JD, Goldberg AL A soluble ATP-dependent proteolytic system responsible for the degradation of abnormal proteins in retic ulocytes. Proc Natl Acad Sci USA 1977; 74: 54-58.

77. Evans DA, Funkenstein H, Abert MS, Scherr PA, Cook NR, Chown NJ, Hebert LE, Hennekins CH, Taylor JO. Prevalence of Alzheimer's disease in a community of older persons - higher than previously reported. J Am Med Assoc 1989; 262: 2551-2556.

78. Feany MB, Dickson DW. Neurodegenerative disorders with extensive tau pathology: a comparative study and review. Ann Neurol 1996; 40: 139-148.

79. Ferri CP, Prince M, Brayne C, Brodaty H, Fratiglioni L, Ganguli M, Hull K, Hasegawa K, Hendrie M, Huang YQ, Jorm A, Mathers C, Menezes PR, Rimmer E, Scazufia M. Global prevalence of dementia: a Delphi consensus study. Lancet 2005; 366: 2112-2117.

80. Forman MS, Trojanowski JQ, Lee VMY. Neurodegenerative diseases: a decade of discoveries paves the way for therapeutic breakthroughs. Nat Med 2004; 10: 1055-1063.

81. Forman MS, Mackenzie IR, Cairns NJ, Swanson E, Boyer PJ, Drachman DA, Jhaveri BS, Karlawish JH, Pestrvik A, Smith TN, Tu PH, Watts GDJ, Markesbery WR, Smith CD, Kimonis VE. Novel ubiquitin neuropathology in frontotemporal dementia with valosin-containing protein gene mutations. J Neuropathol Exp Neurol 2006; 65: 571-581.

82. Forstl $H$. The Lewy body variant of Alzheimer's disease: clinical, pathophysiological and conceptual issues. Eur Arch Psy Clin N 1999; 249: 64-67.

83. Forstl H, Fischer P. Diagnostic confirmation, severity and subtypes of Alzheimer's disease. Eur Arch Psy Clin N 1994; 244: 252-260.

84. Fratiglioni L, Launer LJ, Andersen K, Breteler MM, Copeland JR, Dartigues JF. Incidence of dementia and major subtypes in Europe: A collaborative study of population-based cohorts. Neurology 2000; 54: S10-S15.

85. Funato $H$, Enya $M$, Yoshimura M, Morishima-Kawashima $M$, Ihara Y. Presence of sodium dodecyl sulphate-stable amyloid beta protein dimers in hippocampus CA1 not exhibiting neurofibrillary tangle formation, Am J Pathol 1999; 155: 23-28.

86. Garcia-Sierra F, Hauw JJ, Duyckaerts C, Wischik CM, LunaMunoz J, Mena R. The extent of neurofibrillary pathology in perforant pathway neurons is the key determinant of dementia in the very old. Acta Neuropathol 2000; 100: 29-35.

87. Garraux G, Salmon E, Degueldre C, Lemaire C, Frank G. Medial temporal lobe metabolic impairment in dementia associated with motor neuron disease. J Neurol Sci 1999; 168: 145-150.

88. Gentleman SM, Williams B, Roystan MC, Jagoe R, Clinton J, Perry RH, Ince PG, Allsop D, Polak JM, Roberts GW. Quantification of $\beta / A 4$ protein deposition in the medial temporal lobe: a comparison of Alzheimer's disease and senile dementia of the Lewy body type. Neurosci Lett 1992; 142: 9-12.

89. Gentleman SM, Nash MJ, Sweeting CJ, Graham DI, Roberts GW. $\beta$-amyloid precusor protein ( $\beta A P P)$ as a marker for axonal injury after head injury. Neurosci Lett 1993; 160: 139-144.

90. Giaccone G, Tagliavini F, Linol G, Bouras C, Frigerio L. Down's patients: Extracellular preamyloid deposits precede neuritic degeneration and senile plaques. Neurosci Lett 1989; 97: 232238.

91. Giannakopoulos P, Hof PR, Bouras C. Dementia lacking distinctive histopathology: Clinicopathological evaluation of 32 cases. Acta Neuropathol 1995; 89: 346-355.

92. Giasson BI, Lee VM, Trojanowski JQ. Interactions of amylodogenic proteins. Neuromol Med 2003; 4: 49-58.

93. Gijselinck I, van Mossevelde S, van der Zee J, Sieben A, Philtjens $S$, Heeman B, Engelborghs S, Vandenbulcke $M$, de Baets $G$, Baumer V, Cuijt I, Van de Broek M, Peeters K, Mattheijssens M, Rousseau F, Vandenberghe R, De Jonghe P, Crass P, De Deyn PP, Martin JJ, Cruts M, Van Broeckhoven C. Loss of TBK1 is a frequent cause of frontotemporal dementia in a Belgian cohort. Neurology 2015; 85: 2116-2125.

94. Gitcho MA, Baloh RH, Chakraverty S, Mayo K, Norton JB, Levitch D, Hatanpaa KJ, White CL 3rd, Bigio EH, Caselli R, Baker M, Al-Lozi MT, Morris JC, Pestronk A, Rademakers R, Goate AM, Cairns NJ. TDP-43 A315T mutation in familial motor neuron disease. Ann Neurol 2008; 63: 535-538.

95. Glenner GG, Wong CW. Alzheimer's disease and Down's syndrome: sharing of a unique cerebrovascular amyloid fibril protein. Biochem Biophys Res Commun 1984; 122: 1131-1135.

96. Goate R, Chartier-Harlin MC, Mullan M, Brown J, Crawford F, Fidani L, Giuffra L, Haynes A, Irving N, James L, Mant R, Newton P, Rooke K, Roques P, Talbot C, Pericak-Vance M, Roses A, Williamson R, Rossor M, Owen M and Hardy J. Segregation of a missense mutation in the amyloid precursor protein gene with familial Alzheimer's disease. Nature 1991; 349: 704-706.

97. Goedert M, Wischik CM, Crowther RA, Walker JE, Klug A. Cloning and sequencing of the CDHA-encoding a core protein of the paired helical filament of Alzheimer's disease: Identification of the microtubule-associated protein tau. Proc Natl Acad Sci USA 1988; 85: 4051-4055.

98. Goedert M, Clavaguera F, Tolnay M. The propagation of prion-like protein inclusions in neurodegenerative diseases. Trends Neurosci 2010; 33: 317-325.

99. Grudzien A, Shaw P, Wientraub S, Bigio E, Mash DC, Mesulam MM. The locus caeruleus neurofibrillary degeneration in 
aging, mild cognitive impairment and early Alzheimer's disease. Neurobiol Aging 2007; 28: 327-335.

100. Guillozet AL, Weintraub S, Mash DC, Mesulam MM. Neurofibrillary tangles, amyloid, and memory in aging and mild cognitive impairment. Arch Neurol-Chicago 2003; 60: 729-736.

101. Guo SX, Palaniyappan L, Yang B, Liu ZN, Xue ZM, Feng JF. Anatomical distance affects functional connectivity in patients with achizophrenia and their siblings. Schizophrenia Bul 2014; 40: 449-459.

102. Hainfellner JA, Aanschutz J, Jellinger K, Liberski PP, Gullotta F Budka $\mathrm{H}$. Coexistence of Alzheimer type neuropathology in Creutzfeldt-Jakob disease. Acta Neuropathol 1998; 96: 116-122.

103. Hakim AM, Mathieson G. Dementia in Parkinson's disease: neuropathologic study. Neurology 1979; 29: 1209-1214.

104. Hardy JA, Higgins GA. Alzheimer's disease: the amyloid cascade hypothesis. Science 1992; 256: 184-185.

105. Hawkes CH, Del Tredici K, Braak H. Parkinson's disease: a dual hit hypothesis. Neuropathol Appl Neurobiol 2007; 33: 599-614.

106. Heisz JJ, Gould M, Mclntosh AR. Age-related shift in neural complexity related to task performance and physical activity. J Cognitive Neurosci 2015; 27: 605-613.

107. Helgason T. Epidemiology of mental disorder in Iceland. A geriatric follow-up (preliminary report) Ex Med Inter Cong S 1973; 274: 350-357.

108. Helm N, Duzel S. Lifestyle-dependent health factors, cognitive aging and dementia. Klin Neurophysiol 2010; 41: 116-124.

109. Henderson AS. The risk factors for Alzheimer's disease: a review and a hypothesis. Acta Psychiat Scand 1988; 78: 257-275.

110. Heyman A, Wilkinson WE, Hurwitz BJ, Schmechel D, Sigman AH, Weinberg T, Helms MJ, Swift M. Alzheimer's disease: genetic aspects and associated clinical disorders. Ann Neurol 1983; 14: 507-513.

111. Heyman A, Wilkinson WE, Stafford JA, Helms MJ, Sigmon AH, Weinberg T. Alzheimer's disease: a study of epidemiological aspects. Ann Neurol 1984; 15: 335-341.

112. Hiorns RW, Neal JW, Pearson RCA, Powell TPS. Clustering of ipsilateral cortico-cortical projection neurons to area 7 in the rhesus monkey. P Roy Soc London 1991; 246: 1-9.

113. Hoesen GW, Solodkin A. Some modular features of temporal cortex in humans as revealed by pathological changes in Alzheimer's disease. Cereb Cortex 1993; 3: 465-475.

114. Hyman BT, Tanzi RE. Amyloid, dementia and Alzheimer's disease. Curr Opin Neurol Neu 1992; 5: 88-93.

115. Hyman BT, Phelps CH, Beach TG, Bigio EH, Cairns NJ, Carrillo MC, Dickson DW, Duyckaerts C, Frosch MP, Masliah E, Mirra SS, Nelson PT, Schneider JA, Thal DR, Thies B, Trojanowski JQ, Vinters HV, Montine TJ. National Institute on Aging-Alzheimer's Association guidelines for the neuropathologic assessment of Alzheimer's disease. Alzheimer's Dement 2012; 8: 1-13.

116. Imhof A, Kovari E, von Gunten A, Gold G, Rivara CB, Herrmann FR, Hof PR, Bouras C, Glannakopoulos P. Morphological substrates of cognitive decline in nonagenarians and centenarians: A new paradigm? J Neurol Sci 2007; 257: 72-79.

117. Ironside JW. Pathology of variant Creutzfeldt-Jakob disease. Arch Virol S 2000; 16: 143-151.

118. Jellinger KA. Recent developments in the pathology of Parkinson's disease. J Neural Transm 2002; 62: 347-376.
119. Jellinger KA, Attems J. Challenges of multimorbidity of the aging brain: a critical update. J Neural Transm 2015; 122: 505521.

120. Josephs KA. Frontotemporal dementia and related disorders: Deciphering the enigma. Ann Neurol 2008; 64: 4-14.

121. Kalaria RN, Perry G. Amyloid P component and other acutephase proteins associated with cerebellar A $\beta$ deposits in Alzheimer's disease. Brain Res 1993; 631: 151-155.

122. Kalaria RN, Bhatt SU, Perry G, Lust WD. The amyloid precursor protein in ischaemic brain injury and chronic hypoperfusion. Proc 7th Inter Study Group on Pharm Mem Dis Assoc with Aging, 1993; 91: 294.

123. Kawarabayashi T, Shoji M, Harigaya Y, Yamaguchi H, Hirai S. Expression of amyloid precursor protein in early stage of brain damage. Brain Res 1991; 563: 334-338.

124. Killin LOJ, Starr JM, Shiue IJ, Russ TC. Environmental risk factors for dementia: a systematic review. BMC Geriatrics 2016, 16: 175.

125. Knopman DS. An overview of common non-Alzheimer dementias. Clin Geriatr Med 2001; 17: 281.

126. Knopman DS, Parisi JE, Salviati A, Floriach-Robert M, Boeve BF, Ivnik RJ, Smith GE, Dickson DW, Johnson KA, Petersen LE, McDonald WC, Braak H, Petersen RC. Neuropathology of cognitively normal elderly. J Neuropathol Exp Neurol 2003; 62: 1087-1095.

127. Komori T. Tau positive glial inclusions in progressive supranuclear palsy, corticobasal degeneration and Pick's disease. Brain Pathol 1999; 9: 663-679.

128. Koo JH. Treadmill exercise produces neuroprotective effects in a murine model of Parkinson's disease by regulating the TLR2.MYD88/NF-kappa B signalling pathway. Neuroscience 2017; 356: 102-113.

129. Kotzbauer PT, Cairns NJ, Campbell MC, Racette BA, Tabbal SD, Perlmutter JS. Pathological accumulation of $\alpha$-synuclein and $A \beta$ in Parkinson disease patients with dementia. Arch Neurol 2012; 69: 1326-1331.

130. Kowall NW, Hantraye P, Brouillet E, Beal MF, McKee AC. MPTP induces alpha-synuclein aggregation in the substantia nigra of baboons. NeuroReport 2000; 11: 211-213.

131. Kyrozis A, Ghika A, Stathopoulos P, Vassilopoulos D, Trichopolous D, Trichopoulon A. Dietary and lifestyle variable in relation to incidence of Parkinson's disease in Greece. Eur J Epidemiol 2013; 28: 67-77.

132. Lantos PL. The neuropathology of progressive supranuclear palsy. J Neural Transm 1994; 42: 137-152.

133. Larsson T, Sjogren T, Jacobsen O. Senile dementia: a clinical, sociomedical and genetic study. Acta Psychiatr Scand 1963; 167: 1-259.

134. Levy-Lahad E, Wasco W, Poorkaj P, Romano DM, Oshima J, Pettingell WH, Yu C, Paul D, Jondro PD, Schmidt SD, Wang K, Crowley AC, Fu Y, Guenette SY, Galas D, Nemens E, Wijsman EM, Bird TD, Schellenberg GD, Tanzi RE. Candidate gene for chromosome 1 familial Alzheimer's disease locus. Science 1995; 269: 973-977.

135. Liu Y, Yu CS, Zhang XQ, Liu JQ, Duan YY, Alexander-Bloch AF, Liu B, Jiang TZ, Bullimore ET. Impaired long distance function- 
al connectivity and weighted network architecture in Alzheimer's disease. Cereb Cortex 2014; 24: 1422-1435.

136. Lix LM, Hobson DE, Azimnee M, Leslie WD, Burchell D, Hobson $\mathrm{S}$. Socioeconomic variations in the prevalence and incidence of Parkinson's disease: a population based study. J Epidemiol Commun H 2010; 64: 335-340.

137. Lobo A, Launer LJ, Fratiglioni L, Andersen K, de Carlo A, Breteler MM. Prevalence of dementia and major subtypes in Europe: A collaborative study of population-based cohorts. Neurology 2000; 54: S4-S9.

138. Lobotesis K, Fenwick JD, Phipps A, Ryman A, Swann A, Balard C, McKeith IG, O'Brien JT. Occipital hypoperfusion on SPECT in dementia with Lewy bodies but not Alzheimer's disease. Neurology 2001; 56: 643-649.

139. Lopez-Toledano MA, Shelanski ML. Neurogenic effect of betaamyloid peptide in the development of neural stem cells. J Neurosci 2004; 24: 5439-5444.

140. Luty AA, Kwok JBJ, Thompson EM, Blumsbergs P, Brooks WS, Loy CT, Dobson-Stone C, Panegyres PK, Hecker J, Nicholson GA, Halliday GM, Schofield PR. Pedigree with frontotemporal lobar degeneration-motor neuron disease and Tar DNA binding protein-43 positive neuropathology: genetic linkage to chromosome 9. BMC Neurology 2008; 8: 32.

141. Mackenzie IRA, Hudson LP. Achromatic neurons in the cortex of progressive supranuclear palsy. Acta Neuropathol 1995; 90 : 615-619.

142. Mackenzie IRA, Baker M, Pickering-Brown S, Hsinng GYR, Lindholm C, Dwosh E, Cannon A, Rademakers R, Hutton M, Feldman $\mathrm{HH}$. The neuropathology of frontotemporal lobar degeneration caused by mutations in the progranulin gene. Brain 2006; 129: 3081-3090.

143. Mackenzie IRA, Neumann M, Baborie, Sampathu DM, Du Plessis D, Jaros E, Perry RH, Trojanoswki JQ, Mann DMA, Lee VMY A harmonized classification system for FTLD-TDP pathology. Acta Neuropathol 2011; 122: 111-113.

144. Mackenzie IRA, Neumann M. Reappraisal of TDP-43 pathology in FTLD-U subtypes. Acta Neuropathol 2017; 134: 79-96.

145. Mann DMA, Tucker CM, Yates PO. Topographic distribution of senile plaques, neurofibrillary tangles in the brains of non demented persons of different age. Neuropath App Neurobiol 1987; 13: 123-139.

146. Mann DMA, Jones D. Deposition of amyloid A4 protein within the brains of persons with dementing disorders other than Alzheimer's disease and Down's syndrome. Neurosci Lett 1990; 109: 68-75.

147. Mann DMA, Younis N, Jones D, Stoddart RW. The time course of pathological events in Down's syndrome with particular reference to the involvement of microglial cells and deposits of $\beta$ /A4. Neurodegeneration 1992; 1: 201-215.

148. McKenzie JE, Gentleman SM, Roberts GW, Graham DI, Roston MC. Increased numbers of $\beta$ APP-immunoreactive neurons in the entorhinal cortex after head injury. NeuroReport 1994; 6: 161-164.

149. McCormack AL, Mak SK, Di Monte DA. Increased alpha-synuclein phosphorylation and nitration in the aging primate substantia nigra. Cell Death Dis 2012; 3: e315.
150. Miller DF, Hicks SP, D’Amato CJ, Landis JR. A descriptive study of neuritic plaques and neurofibrillary tangles in an autopsy population. Am J Epidemiol 1984; 20: 331-341.

151. Minoshima S, Foster NL, Sima AAF, Frey KA, Abin RL, Kuhl DE. Alzheimer's disease versus dementia with Lewy bodies: cerebral metabolic distinction with autopsy confirmation. Ann Neurol 2001; 50: 358-365.

152. Montembeault M, Joubert S, Doyon J, Carrier J, Gagnon JF, Monchi O, Lungu O, Belleville S, Brambati SM. The impact of aging on gray matter structural covariance networks. Neuroimage 2012; 63: 754-759.

153. Montine TJ, Phelps CH, Beach TG, Bigio EH, Cairns NJ, Dickson DW, Duyckaerts C, Frosch MP, Masliah E, Mirra SS, Nelson PT, Schneider JA, Thal DR, Trojanowski JQ, Vinters HV, Hyman BT. National Institute on Aging; Alzheimer's Association. National Institute on Aging-Alzheimer's Association guidelines for the neuropathologic assessment of Alzheimer's disease: a practical approach. Acta Neuropathol 2012; 23: 1-11.

154. Moran RJ, Symmonds M, Dolan RJ, Friston KJ. The brain ages optimally to model its environment: Evidence from sensory learning over the adult lifespan. PLoS Comput Biol 2014; 10: e1003422.

155. Mukherjee O, Pastor P, Cairns NJ, Chakraaverty S, Kauwe JSK, Shears S, Behrens MI, Budde J, Hinrichs AL, Norton J, Levitch D, Taylor-Reinwald L, Gitcho M, Tu PH, Grinberg LT, Liscic RM, Armendariz J, Morris JC, Goate AM. HDDD2 is a familial frontotemporal lobar degeneration with ubiquitin-positive taunegative inclusions caused by a missense mutation in the signal peptide of progranulin. Ann Neurol 2006; 60: 314-322.

156. Muntane G, Ferrer J, Martinez-Vicente M. Alpha-synuclein phosphorylation and truncation are normal events in the adult human brain. Neuroscience 2012; 200: 106-119.

157. Newell KL, Boyer P, Gomez-Tortosa E, Hobbs W, Hedley-Whyte ET, Vonsattel JP, Hyman BT. Alpha-synuclein immunoreactivity is present in axonal swellings in neuroaxonal dystrophy and acute traumatic brain injury. J Neuropath Exp Neurol 1999; 58 : 1263-1268.

158. Nigam SM, Xu SH, Kritikon JS, Marosi K, Brodin L, Mattson MP. Exercise and BDNF reduce $\mathrm{A}$ beta production by enhancing alpha-secretase processing of APP. J Neurochem 2017; 142: 286-296.

159. Novikoff AB, Beautay H, De Duve C. Electron microscopy of lysome rich fractions from rat liver. J Biophys Biochem Cy 1956; 2: 179-184.

160. Oyama F, Shimada H, Oyama R, Titani K, Ihara Y. $\beta$-amyloid protein precursor and tau mRNA levels versus $\beta$-amyloid plaque and NFT in the aged human brain. J Neurochem 1993; 60: 1658-1664.

161. Oyama F, Shimada H, Oyama R, Ihara Y. Apolipoprotein E genotype, Alzheimer pathologies and related gene expression in the age population. Mol Brain Res 1995; 29: 92-98.

162. Pan WJ, Wu GY, Li CX, Lin FC, Sun JM, Lei H. progressive atrophy in the optic pathway and visual cortex of early blind Chinese adults: A voxel-based morphometry magnetic resonance imaging study. Neuroimage 2007; 37: 212-220. 
163. Pearson RCA, Esiri MM, Hiorns RW, Wilcock GK, Powell TPS. Anatomical correlates of the distribution of the pathological changes in the neocortex in Alzheimer's disease. Proc Natl Acad Sci USA 1985; 82: 4531-4534.

164. Perez M, Cuadros R, Benitez MJ, Jimeniz JS. Interaction of Alzheimer's disease $A \beta$ peptide 25-35 with tau protein and with a tau peptide containing the microtubule binding domain. J Alzheimers Dis 2004; 6: 461-470.

165. Quigley H, Colloby SJ, O’Brien JT. PET imaging of brain amyloid in dementia: a review. Int J Geriatr Psych 2011; 26: 991-999.

166. Rademakers R, Hutton $M$. The genetics of frontotemporal lobar degeneration. Curr Neurol Neurosci 2007; 7: 434-442.

167. Reed LA, Wszolek ZK, Hutton M. Phenotypic correlates in FTDP-17. Neuropathol Aging 2001; 22: 89-107.

168. Regland B, Gottfries CG. The role of amyloid $\beta$-protein in Alz heimer's disease. Lancet 1992; 340: 467-469.

169. Renton AE, Majounie E, Waite A, Simón-Sánchez J, Rollinson S, Gibbs JR, Schymick JC, Laaksovirta H, van Swieten JC, Myllykangas L, Kalimo H, Paetou A, Abramzon Y, Remes AM, Kaganovitch A, Scholz SW, Duckworth J, Ding J, Harmer DW, Hernandez DG, Johnson JO, Mok K, Ryten M, Trabzuni D, Guerreiro RJ, Orrell RW, Neal J, Murray A, Pearson J, Jansen IE, Sondervan D, Seelaar H, Blake D, Young K, Halliwell N, Callister JB, Toulson G, Richardson A, Gerhard A, Snowden J, Mann D, Neary D, Nalls MA, Peuralinna T, Jansson L, Isoviita VM, Kalvorinne AL, Hölttä-Vuori M, Ikonen E, Sulkava R, Benatar M, Wuu J, chio A, Restagno G, Borghero G, Sabatelli M, The ITALSGEN Consortium, Heckerman D, Rogaeva E, Zinman L, Rothstein JD, Sendtner M, Drepper C, Eichler EE, Alkan C, Abdullaev Z, Pack SD, Dutra A, Pak E, Hardy J, Singleton A, Williams NM, Heutink P, Pickering-Brown S, Morris HR, Tienari PJ, Traynor BJ. A hexanucleotide repeat expansion in C9ORF72 is the cause of chromosome 9p21-linked ALS-FTD. Neuron 2011; 72: 257-268.

170. Ritchie K, Touchon J. Heterogeneity in senile dementia of the Alzheimer type: Individual differences, progressive deterioration or clinical subtypes? J Clin Epidemiol 1992; 45: 1391-1398.

171. Roberts GW, Gentleman SM, Lynch A, Murray L, Landon M, Graham DI. $\beta$-amyloid protein deposition in the brain after severe head injury: implications for the pathogenesis of Alzheimer's disease. J Neurol Neurosurg Psychiatry 1994; 57: 419-425.

172. Rosser NN. Parkinson's disease and Alzheimer's disease as disorders of the isodendritic core. Brit Med J 1981; 282: 15881590.

173. Saaksjarvi K, Kneht P, Mannisto S, Lyytinen J, Jaaskelainen T, Kanerva N, Heliovaara M. Reduced risk of Parkinson's disease associated with lower body mass index and heavy leisure-time physical activity. Eur J Epidemiol 2014; 29: 285-292.

174. Sampathu DM, Neumann M, Kwong LK, Chou TT, Micsenyi M, Truax A, Bruce J, Grossman M, Trojanowski JQ, Lee VM. Pathological heterogeneity of frontotemporal lobar degeneration with ubiquitin-positive inclusions delineated by ubiquitin immonohistochemistry and novel monoclonal antibodies. Am J Pathol 2006; 189: 1343-1352.

175. Saper CB, Wainer BH, German DC. Axonal and transneural transport in the transmission of neurological disease: potential role in system degenerations including Alzheimer's dis ease. Neuroscience 1987; 23: 389-398.
176. Saunders A, Strittmater W, Schmechel D, St. George-Hyslop P, Pericak-Vance M, Joo S, Rose B, Gasella J, Crapper-MacLachan D, Albersts M, Hulette C, Crain B, Goldgaber D, Roses A. Association of apolipoprotein $\mathrm{E}$ allele $\mathrm{e} 4$ with late-onset familial and sporadic Alzheimer's disease. Neurology 1993; 43: 1467-1472.

177. Scheff SW, Price DA. Synapse loss in the temporal lobe in Alzheimer's disease. Ann Neurol 1993; 33: 190-199.

178. Schulz-Schaeffer WJ, Giese A, Windl O, Kretschmar HA. Polymorphism at codon 129 of the prion protein gene determines cerebellar pathology in Creutzfeldt-Jakob disease. Clin Neuropathol 1996; 15: 353-357.

179. Sherrington R, Rogaev EI, Liang Y, Rogaeva EA, Levesque G, Ikeda M, Chi H, Lin C, Li G, Holman K, Tsuda T, Mar L, Foncin JF, Bruni AC, Moulese MP, Sorbi S, Rainero I, Pinessi L, Nee L, Chumakov I, Pollen D, Brookes A, Sauseau P, Polinski RJ, Wasco RJ, Dasilva HAR, Haines JL, Pericak-Vance MA, Tanzi RE, Roses AD, Fraser PE, Rommens JM, St George-Hyslop PH. Cloning of a gene bearing missense mutations in early onset familial Alzheimer's disease. Nature 1993; 375: 754-760.

180. Shinotoh H, Namba H, Yamaguchi M, Fukushi K, Nagatsuka S, Iyo M, Asahina M, Hattori T, Tanada S, Irie T. Positron emission tomographic measurement of acetylcholinesterase activity reveals differential loss of ascending cholinergic systems in Parkinson's disease and progressive supranuclear palsy. Ann Neurol 1998; 46: 62-69.

181. Siette J, Westbrook RF, Cotman C, Sidhu K, Sachdev P, Valenzuela MJ. Age-specific effects of voluntary exercise on memory and the older brain. Biol Psychiat 2013; 73: 435-442.

182. Solesio-Jofre E, Serbruyns L, Woolley DG, Mantini D, Beets IAM, Swinnen SP. Aging effects on the resting state motor network and interlimb coordinations. Hum Brain Mapp 2014; 35: 39453961.

183. Sonnen JA, Cruz KS, Henny LS, Woltzer R, Leverenz JB, Montine KS, Jack CR, Kaye J, Lim R, Larson EB, White L, Montine TJ. Ecology of the aging human brain. Arch Neurol 2011; 68: 10491056.

184. Sparks DL, Hunsaker JC, Scheff SW, Kryscio RJ, Henson JL, Markesbery WR. Cortical senile plaques in coronary artery disease, aging and Alzheimer's disease. Neurobiol Aging 1990; 11: 601-607.

185. Sparks DL. Huaichen L, Scheff SW, Coyne CM, Hunsaker JC. Temporal sequence of plaque formation in the cerebral cortex of non-dented individuals. J Neuropath Exp Neurol 1993; 52: 135-142.

186. Spear PD. Neural bases of visual deficits during aging. Vision Res 1993; 33: 2589-2609.

187. Steiner JA, Angot E, Brunden P. A deadly spread: cellular mechanisms of $\alpha$-synuclein transfer. Cell Death Diff 2011; 18: 14251433.

188. Steinling M, Defebvire L, Duhamel A, Lecouffe P, Lavenu I, Pasquier F, Charpentier P. Is there a typical pattern of brain SPECT imaging in Alzheimer's disease? Demen Geriatr Cogn 2001; 12: 371-378.

189. Stephenson DT, Rash K, Clemens JA. Amyloid precursor protein accumulates in regions of neurodegeneration following focal cerebral ischemia in the rat. Brain Res 1992; 593: 128-135. 
190. Strittmatter WJ, Wiesgraber KH, Huang DY, Dong LM, Salvesen GS, Pericak-Vance M, Schmechel D, Saunders AM, Goldgaber D, Roses D. Binding of human apolipoprotein $E$ to synthetic amyloid- $\beta$-peptide: isoform specific effects and implications for late-onset Alzheimer's disease. Proc Natl Acad Sci USA 1993; 90: 8098-8102.

191. Sun Y, Yin QH, Fang R, Yan XX, Wang Y, Bezerianos A, Tang HD, Miao F, Sun JF. Disrupted functional brain conectivity and its association to structural connectivity in amnestic mild cog nitive impairment and Alzheimer's disease. PLoS One 2014; 9: e96505.

192. Tabaton M, Perry G, Gambetti L, Manello V, Gambetti P. Influence of neuronal location on antigenic properties of neurofibrillary tangles. Ann Neurol 1988; 23: 604-610.

193. Talbot PR, Goulding PJ, Lloyd JJ, Snowden JS, Neary D, Testa HJ. Interrelation between classic motor neuron disease and frontotemporal dementia: neuropsychological and single-photon emission computed tomography study. J Neurol Neurosurg Psychiatry 1995; 58: 541-547.

194. Torack RM, Miller JW. Immunoreactive changes resulting from dopaminergic denervation of the dentate gyrus of the rat hippocampal formation. Neurosci Lett 1994; 169: 9-12.

195. Vermersch P, Frigand B, Delacourte A. Mapping of neurofibrillary degeneration in Alzheimer's disease: evaluation of heterogeneity using the quantification of abnormal tau proteins. Acta Neuropathol 1992; 85: 48-54.

196. Vinters HV. Cerebral amyloid angiopathy and Alzheimer's disease: Two entities or one? J Neurol Sci 1992; 112: 1-3.

197. Wakabayashi K, Honer WG, Masliah E. Synapse alterations in the hippocampal entorhinal formation in Alzheimer's disease with and without Lewy body dementia. Brain Res 1994; 667: 24-32.

198. Wallace WC, Bragin V, Robakis NK, Sambamurti K, Vanderputten D, Merril CR, Davis KL, Santucci AC, Haroutunian V. Increased biosynthesis of Alzheimer amyloid precursor protein in the cerebral cortex of rats with lesions of the nucleus basalis of Meynert. Mole Brain Res 1991; 10: 173-178.

199. Ward AM, Mormino EC, Huijbers W, Schultz AP, Hedden T, Sperling RA. Relationships between default-mode network connectivity, medial temporal lobe structure, and age-related memory deficits. Neurobiol Aging 2015; 36: 265-272.

200. Watanabe M, Liao JH, Jara H, Sakai O. Multispectral quantitative MR imaging of the human brain: Lifetime age-related effects. Radiographics 2013; 33: 1305-1319.

201. Watts GD, Wymer J, Kovach MJ, Mehta SG, Mumm S, Darvish D, Pestronk A, Whyte MP, Kimonis VE. Inclusion body myopathy associated with Paget disease of bone and frontotemporal dementia is caused by mutant valosin-containing protein. Nat Genet 2004; 36: 377-381.

202. Williams DR, de Silva R, Paviour DC, Pittman A, Watt HC, Kilford L, Holton JL, Revesz T, Lees AJ. Characteristics of two distinct clinical phenotypes in pathologically proven progressive supranuclear palsy: Richardson's syndrome and PSP-parkinsonism. Brain 2005; 128: 1247-1258.

203. Wisniewski T, Ghiso J, Frangione B. Alzheimer's disease and soluble A $\beta$. Neurobiol Aging 1994; 15: 143-152.

204. Wobst HJ, Wesolowski SS, Chadchankar J, Delsing L, Jacobsen S, Mukherjee J, Deeb TZ, Dunlop J, Brandon NJ, Moss SJ.
Cytoplasmic relocalization of TAR DNA binding protein 43 is not sufficient to reproduce cellular pathologies associated with ALS in vitro. Front Mol Neurosci 2017; 10: 46.

205. Woodward M, Mackenzie IRA, Hsiung GYR, Jacova C, Feldman H. Multiple brain pathologies in dementia are common. Eur Geriatr Med 2010; 1: 259-265.

206. Yamada M. Senile dementia of the neurofibrillary tangle type (tangle-only dementia): Neuropathological criteria and clinical guidelines for diagnosis. Neuropathology 2003; 23: 311-317.

207. Yu L, Boyle PA, Leurgans S, Schnieder JA, Kryscio RJ, Wilson RS, Bennett DA. Effect of common neuropathologies on progression of late life cognitive impairment. Neurobiol Aging 2015; 36: 2225-2231. 